\title{
In Australasia, gender is still on the agenda in geosciences
}

\author{
Heather K. Handley ${ }^{1,2}$, Jess Hillman ${ }^{2,3}$, Melanie Finch ${ }^{2,4}$, Teresa Ubide ${ }^{2,5}$, Sarah Kachovich ${ }^{2,6}$, Sandra McLaren ${ }^{2,7}$, \\ Anna Petts $^{2,8}$, Jemma Purandare ${ }^{2,9}$, April Foote ${ }^{1,2}$, and Caroline Tiddy ${ }^{2,10}$ \\ ${ }^{1}$ Department of Earth and Environmental Sciences, Macquarie University, Sydney, NSW 2109, Australia \\ ${ }^{2}$ Women in Earth and Environmental Sciences Australasia (WOMEESA) Network, Sydney, NSW 2127, Australia \\ ${ }^{3}$ GNS Science, 1 Fairway Drive, Avalon, Lower Hutt 5010, New Zealand \\ ${ }^{4}$ School of Earth, Atmosphere and Environment, Faculty of Science, Monash University, Clayton, VIC 3800, Australia \\ ${ }^{5}$ School of Earth and Environmental Sciences, University of Queensland, Brisbane QLD 4072 Australia \\ ${ }^{6}$ International Ocean Discovery Program, Texas A\&M University, College Station, TX, 77845, USA \\ ${ }^{7}$ School of Earth Sciences, The University of Melbourne, Victoria 3010, Melbourne, Australia \\ ${ }^{8}$ Geological Survey of South Australia, Level 4, 11 Waymouth Street, Adelaide, South Australia 5000, Australia \\ ${ }^{9}$ Griffith Centre for Coastal Management, Griffith University, Southport, QLD 4222, Australia \\ ${ }^{10}$ Future Industries Institute, University of South Australia, Adelaide, SA 5000, Australia
}

Correspondence: Heather Handley (heather.handley@mq.edu.au)

Received: 29 February 2020 - Revised: 25 May 2020 - Accepted: 5 August 2020 - Published: 24 September 2020

\begin{abstract}
Diversity and inclusion in the workplace optimise performance through the input of a range of perspectives and approaches that drive innovation and invention. However, gender inequity is prevalent throughout society and females remain underrepresented in geoscience careers. This study provides the current status of gender equity in geosciences throughout Australasia within the context of broader gender equity policy, frameworks and initiatives and suggests additional solutions and opportunities to improve gender equity and the retention of women in the geoscience workforce. At an individual institutional level in academia, females make up between $23 \%-52 \%$ of the total geoscience departmental or school staff in Australia, 26\%-39\% of the total staff in New Zealand, $29 \%$ of total staff at the University of Papua New Guinea and $18 \%$ at the University of the South Pacific. Significant gender imbalance exists at more senior levels, with disproportionately more males than females, a pattern typical of many Science Technology Engineering and Maths (STEM) disciplines. Gender inequity is prevalent within the general membership, committee roles and in award recipients of Australasian geoscience professional associations. Within the Geological Society of Australia and Geoscience Society of New Zealand, only $4 \%(n=47)$ and $18 \%(n=161)$, respectively of past award recipients for national and general awards were female. All past awards considered in this study that are named in honour of a person were named in honour
\end{abstract}

of a man $(n=9)$. In recent years, women-focused networks have begun to play an invaluable role to support the retention and promotion of women in geosciences and provide a supportive mentoring environment to discuss challenges and share advice. The improved visibility of women in the geoscientific community is an ongoing issue that can in part be addressed through the development of public databases of women geoscientists. These provide a list of women geoscientists that encourages and supports the achievement of gender balance of invited talks, job shortlisting and on panels, as well as in the media. This work highlights that more must be done to actively reduce and eliminate sexual harassment and assault in university and field environments. We emphasise that particular efforts are required to make geoscience careers more inclusive and safer, through the establishment of specific codes of conduct for field trips. Shared learning of best practices from evidence-based approaches and innovative solutions will also be of value in creating positive change. Greater engagement from the wider geoscientific community, and society in general, is required for the success of gender equity initiatives. Identified solutions and opportunities must target all levels of education and career development. Additional data in future should be collected to look beyond gender to monitor and assess intersectionality. Improved efforts to understand why women leave STEM careers will help to address the "leaky pipeline" and determine 
the initiatives that will be most effective in creating long term sustainable change.

\section{Introduction}

Workplace diversity and inclusion is central to driving innovation and invention because it widens perspectives and approaches, optimising performance (Green et al., 2002; Johnson, 2018). The 2017 World Economic Forum Gender Gap report estimated that USD 5.3 trillion could be added to global GDP by closing the gender gap in economic participation by $25 \%$ by 2025 (Schwab et al., 2017). However, progress is slow and women and other underrepresented groups continue to face barriers to careers and career progression within Science, Technology, Engineering, and Maths (STEM) fields, including Geosciences (the latter including Earth and Environmental Sciences). This is due to a range of factors including discrimination, bias, stereotypes, and workplace structure and culture (e.g., $\mathrm{Su}$ and Rounds, 2015; Dutt et al., 2016). Solutions are needed that move beyond approaches that "fix women", which put the onus on women to adapt, and build fairer workplaces by focusing on institutional change to "fix the system". While many current government, institutional and grass-roots initiatives focus on improving gender equity, it is expected that these initiatives will also help increase diversity of minority groups since some strategies are not targeted at helping women explicitly, but rather reducing bias in systems around hiring, awarding grants, and promotions, for example.

Women are not a minority, they represent around half of the World's population (49.6\% in 2017; Ritchie and Roser, 2019), and yet they are consistently behind men on every critical indicator. Gender equality (Sustainable Development Goal 5) is laid out as an important goal for 2030; however, it is projected to take around 100 years on average to achieve this goal according to the World Economic Forum (2019b). Without a more deliberate, data-driven focus on the needs of women and girls in particular, progress toward a wide range of objectives will suffer. Overcoming the deeply entrenched barriers that impede progress for women and girls can seem like a daunting challenge, but it is also a valuable opportunity. Data alone do not solve problems but enable us to ask more insightful questions and to collect and use this information to inform policy interventions (Lopes and Bailur, 2018). Robust gender data are essential to drive policies related to gender equity and equality; however, policymakers frequently only have access to biased or incomplete data sets that do not accurately reflect the lives of women and girls (Greenway, 2019).

In Australasia, defined here as Australia, New Zealand (NZ), Melanesia, and the western Pacific Ocean islands of Polynesia, the lack of diversity in STEM disciplines, particularly in academia, has long been recognised (e.g., Mills et al., 2006), but it has only been relatively recently that a groundswell of support to change the status quo has developed in some of these countries. Although geoscience departments and schools in several Australian universities were included within their university's data for the Science in Gender Equity (SAGE) Pilot Program, we do not yet have a good understanding of the status of gender equity in geosciences across Australasia within academia, industry, government and professional associations.

In this paper we present the current status of gender equity in geosciences in Australasia as expressed through a compilation of publicly available information on gender in academic institutions, and success in Australian (Australian Research Council, ARC) and New Zealand (Royal Society of NZ, Marsden Fund) funding schemes. We also present available information on gender balance in professional society membership (Geological Society of Australia, GSA, and Australian Institute of Geoscientists, AIG), committee structure (GSA) and award recipients (GSA and the Geoscience Society of New Zealand, GSNZ). The results indicate some positive change in recent years, but highlights that Australasian geoscience has much work to do to achieve gender equity. We see this paper as the first step in providing a baseline on the current status of gender equity in geosciences in the region. The Women in Earth and Environmental Sciences Australasia (WOMEESA) network is used as a case study to explore the value and role of women-focused networks in driving and supporting gender equity in geoscience. The study also recommends additional steps forward towards achieving gender equity in geosciences.

\section{Current status of workforce gender equity and equality in the Australasian landscape}

An understanding of broader policy and legal frameworks within each country provides context and helps develop insight to inequity and inequality in geosciences. Here we provide brief overview of the current status of gender equity and equality within the workforce within Australasia, highlighting great disparity within the region. A global assessment of the status of legal gender discrimination is provided by The World Bank's "Women, Business and the Law" data (World Bank, 2020), where a higher ranking or score reflects more gender equal laws. The latest 2019 data show that Australia and New Zealand rank 19th (96.9 out of 100) and 24th (94.4 out of 100), respectively, out of 190 economies. Other Australasian countries rank lower than Australia and New Zealand (87th to 164th) due to restrictive laws and regulations affecting women's ability to earn equal pay for work of equal value and/or to work in the same sectors and industries as men. For example, Papua New Guinea (PNG) has no laws against sexual harassment in the workplace and in Vanuatu there is no law prohibiting discrimination in the workplace on the basis of gender. Tonga, PNG, Vanuatu 
and the Solomon Islands score 0 out of 100 for "parenthood" with no provision of paid parental leave to mothers or fathers and the lack of protection of jobs for pregnant workers. The labour force participation rate of women, expressed as a percent of the working-age population provided by the International Labour Organisation (ILO, 2020, https: //ilostat.ilo.org/data/country-profiles/) shows that the Australasian island nations of Fiji (38.6\%, 2016 data), Vanuatu (58.1\%, 2010 data), Papua New Guinea (47.7\%, 2010 data), and Samoa $(31.5 \%, 2017$ data) are generally lower than that for Australia $(61.0 \%, 2019$ data) and New Zealand (65.6\%). The World Economic Forum Global Gender Gap Index measures the extent of gender-based gaps within four areas: economic participation and opportunity, education attainment, health and survival, and political empowerment. In the 2020 Global Gender Gap report (World Economic Forum, 2019b) Australasian countries show variable ranking. New Zealand is ranked 6th on the global scale, Australia ranks 44th with a low score on political empowerment, while Fiji, Vanuatu, Papua New Guinea all appear in the lower portion of the 153 countries listed (103rd, 126th and 127th, respectively).

Despite the recognised remuneration potential, gender wage gap data from the Organisation for Economic Cooperation and Development (OECD) available for Australia and New Zealand (OECD, 2020) show a gender wage gap of $11.7 \%$ for Australia, and $7.9 \%$ for New Zealand for full-time employees. However, the Australian Government 2018-2019 Workplace Gender Equality Agency (WGEA) data reveal progress towards workplace gender equity, showing a $20.8 \%$ drop in the gender pay gap, a significant increase in measures to take action on family and domestic violence (policy, strategy and/or paid domestic violence leave), an increase in flexible work arrangements and in having gender equality policies or strategies (Workplace Gender Equality Agency, 2019). Yet on average, men in the general Australian workforce earn close to AUD 26000 more per year than women. The Australian mining sector WGEA data show an encouraging growth in the number of female managers in the last five years and similar representation in managerial roles relative to the proportion of women in the mining workforce, although only $15 \%$ of the sector's workforce are women.

In New Zealand, a 2015 report by Statistics New Zealand found that Natural and Physical Sciences (e.g., biology, chemistry, earth science and mathematics) was the only field of study with no gender segregation (Statistics New Zealand, 2015). Men and women comprised $51 \%$ and $49 \%$ of people with qualifications in this field, respectively. The study also found that in the field of earth sciences, young women (20-29 years old) represent less than $50 \%$ of the workforce. Differences in research score and age explain less than half of the approximately NZD 400000 lifetime gender pay gap in NZ universities (Brower and James, 2020).

\section{Approach and terminology}

Gender is one component of diversity in workplaces but there are many other ways in which society is diverse, including differences in ethnicity, language, culture, social roles, sexual orientation, education, and income, among other attributes. In this study we consider gender equity to be the fair treatment of women and men, respective of their needs. This may involve equal treatment or can involve treatment that is different, but considered equivalent in terms of rights, benefits, obligations and opportunities (Mencarini, 2014). We define gender equality as whereby all human beings, irrespective of gender, are able to develop their personal abilities and choices free of limitations imposed by stereotypes, rigid gender roles, and prejudices. This does not mean that everyone has to become the same, but that an individual's rights, responsibilities and opportunities are not dependent on their gender (Mencarini, 2014). We acknowledge that gender goes beyond the binary division of "male" and "female" or "man" and "woman". However, data on non-binary gender identification was insufficient for analysis and so in this work we have focused on binary data, noting additional gender identification where available.

\subsection{Compilation of institutional gender data by career level}

New data are presented (Table S1 in the Supplement and Sect. 4.2.1) for academic staff by gender and career level at the institutional level from publicly available university geoscience departmental or school websites for Australian and New Zealand universities. Universities were selected based on the top ten Australian and New Zealand universities in the Quacquarelli Symonds (QS) and the Times Higher Education university rankings. Inherent in the compilation of the data is the assumption that we can identify a person's gender by their name and appearance (rather than self-identification) and that we only consider binary gender categories. The employment levels considered included academic levels A to E, where: Level A represents Associate Lecturer/Assistant Lecturer/Research Associate, Level B represents Lecturer/Research Fellow, Level C represents Senior Lecturer/Senior Research Fellow, Level D represents Associate Professor/Reader and Level E represents Professor. Assumptions were required to place academic staff where level is not indicated through job titles (e.g., Teaching Fellow). As such, we allocated Research/Teaching Fellows to Level B, Senior Research/Teaching fellows to Level C, Principal Research Fellows to Level D and Research Professors to Level E. Where job title was not indicated the staff member was not included. Postdoctoral Fellows were attributed to Level A. Professor (Level E) does not include Emeritus Professors. Visiting and honorary positions were also excluded. Other limitations include that websites might not be updated often enough to capture accurate staffing profiles at 


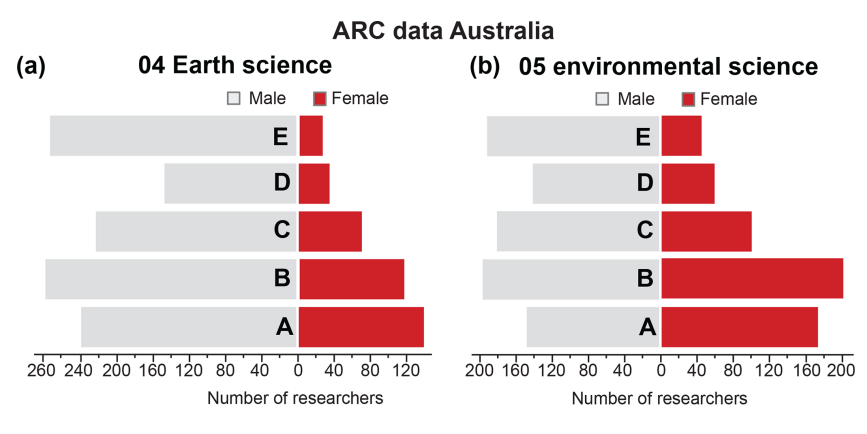

Number of staff at universities

$$
\text { (c) }
$$
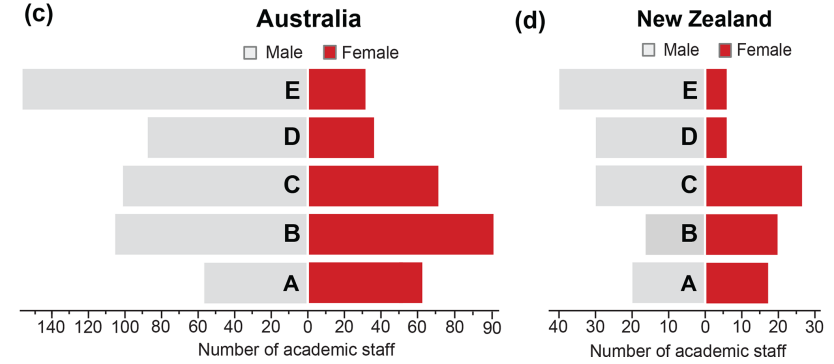

Figure 1. Staff profile by headcount reported by the Australian Research Council (ARC) Excellence in Research for Australia (ERA) 2018 evaluation (Australian Research Council, 2019). Data displayed by two-digit Fields of Research for (a) Earth Sciences (FoR 04) and (b) Environmental Sciences (FoR 05). Note ERA 2018 data only considers staff reported as female or male and excludes 40 staff that were reported as " $X$ " in ERA 2018. Headcount of women working in Geosciences within the top 10 universities in Australia (c) and top 6 in New Zealand (d) according to the Quacquarelli Symonds (QS) World University Rankings and The Times Higher Education World University Rankings for 2019. The employment levels considered included academic levels A to E, where: Level A represents Associate or Assistant Lecturer/Research Associate, Level B represents Lecturer/Research Fellow, Level C represents Senior Lecturer/Senior Research Fellow, Level D represents Associate Professor/Reader and Level E represents Professor. See Sect. 3.1 and Table S1 for additional details.

the time of data collection, in particular the frequent movement of fixed-term Level A staff (Associate/Assistant Lecturers and Research Associates). The University of South Australia, Lincoln University and Auckland University of Technology were not included in the compilation (Fig. 1) as they have few staff in fields relevant to earth and environmental science or geoscience and sufficient data could not be extracted.

\subsection{Compilation of professional association and WOMEESA data}

The Geological Society of Australia (GSA) provided membership gender data for 2018 and 2019 for this study along with gender representation on current (2019-2020) divisional and specialist group committees, which is presented in Table S2. Information on committee members is also pub- licly available on the GSA website (https://www.gsa.org.au/, last access: 11 February 2020). We have compiled longitudinal data on gender representation in past award recipients for national and general awards from the GSA and the Geoscience Society of New Zealand as provided on their respective webpages (Table S3 and summarised in Table 1). We have had to make the assumption that we can identify an awardee's gender by their name and appearance (rather than self-identification) and that we only consider binary gender categories. We also recorded the assumed gender of the medal/award honouree if applicable. WOMEESA membership profile data and the overview of results from a membership survey were provided by WOMEESA (Sect. 7).

\section{Gender equity in Australasian higher education}

Despite recent progress in some countries, women in higher education continue to experience inequity and inequality at a number of levels and gender-specific barriers that can impede completion of undergraduate degrees and their advancement in research careers, particularly in STEM fields, including geosciences. These barriers can include: unconscious biases that negatively influence the perception of women's abilities; social and cultural factors, such as an unequal distribution of domestic labour; and sexual and gender-based harassment (Australian Academy of Science, 2019; Dutt et al., 2016; Greider et al., 2019; Lerback and Hanson, 2017). In this section we provide further insight to these barriers within the higher education context and investigate gendered outcomes for research funding in Australasia. We highlight current gender inequities in geoscience research staff profiles and provide new data on gender balance in Australasian university geoscience departments and institutions.

\subsection{Undergraduate and postgraduate level}

Recent undergraduate enrolment figures in Australia and New Zealand show that there are more females than males enrolled in university courses when all disciplines are considered (Australian Bureau of Statistics, 2019; AWIS, 2011; Ministry of Education New Zealand, 2018a). However, data available for Australia show an overall gender pay gap in the median starting salary of Australian undergraduates (all disciplines) in their first full-time employment by study area, with males being paid AUD 3600 (6\%), AUD 1100 (2\%) and AUD $3000(5 \%)$ more than females starting work in 2016, 2017 and 2018, respectively (Australian Bureau of Statistics, 2019). While enrolment in natural and physical sciences at university in Australia and New Zealand shows around equal gender representation (AWIS, 2011; Australian Bureau of Statistics, 2019), there has been an overall decline in the total number of students enrolled in geoscience degrees in Australia since 2013 (Cohen, 2018). A pattern that is also reflected in geoscience enrolments in the United Kingdom 
Table 1. Summary of the gender of past award recipients for national and general awards of the Geological Society of Australia (GSA) and Geoscience Society of New Zealand (GSNZ).

\begin{tabular}{llrr|rrl}
\hline Name of award & Society & \multicolumn{2}{c|}{$\begin{array}{c}\text { No. of } \\
\text { awardees }\end{array}$} & $\begin{array}{c}\text { Percentage of } \\
\text { awardees }\end{array}$ & \multirow{2}{*}{$\begin{array}{l}\text { Gender of medal } \\
\text { honouree }\end{array}$} \\
\cline { 2 - 5 } & & Female & Male & Female & Male & \\
\hline A. E. Ringwood Medal & GSA & 0 & 4 & 0 & 100 & Male \\
E. S. Hills Medal & GSA & 1 & 3 & 25 & 75 & Male \\
Joe Harms Medal & GSA & 0 & 13 & 0 & 100 & Male \\
S. W. Carey Award & GSA & 0 & 12 & 0 & 100 & Male \\
W. R. Browne Award & GSA & 1 & 13 & 7 & 93 & Male \\
\hline McKay Hammer & GSNZ & 4 & 29 & 12 & 88 & Male \\
Hochstetter Lecture & GSNZ & 3 & 30 & 9 & 91 & Male \\
Kingma Award & GSNZ & 10 & 22 & 31 & 69 & Male \\
NZ Geophysics Award & GSNZ & 3 & 28 & 10 & 90 & Not applicable \\
Harold Wellman & GSNZ & 5 & 27 & 16 & 84 & Male \\
\hline
\end{tabular}

(e.g., Boatright et al., 2019). Therefore, it is paramount that geoscience students of all genders are attracted to geoscience careers and supported throughout their careers to avoid a future shortage of skills and approaches.

One significant challenge that Universities need to address as a matter of priority is sexual assault and sexual harassment within the university environment and particularly on field trips, which form an integral part of many geoscience degrees. A 2013 study of 666 international field scientists, both male and female, found that $72 \%$ of the scientists had seen or heard about verbal harassment in the field, $64 \%$ had experienced sexual harassment in the field themselves, and over $20 \%$ had experienced assault (Clancy et al., 2014). Similarly, a recent global survey of over 4000 scientists revealed that nearly two-thirds of respondents reported witnessing bullying or harassment and $43 \%$ said it had occurred in the workplace (Abbott, 2020). In Australia, the "Change the Course: National Report on Sexual Assault and Sexual Harassment at Australian Universities (2017)" highlighted the nature, prevalence and underreporting of sexual assault and sexual harassment at Australian universities through a national survey (Australian Human Rights Commission, 2017). The survey had 30000 student respondents, representing 39 Australian universities, and revealed that one in five students were sexually harassed (excluding travel to or from university), and $1.6 \%$ were sexually assaulted (including travel to and from university) in a university setting in 2016. Women were twice as likely to be sexually harassed and three times as a likely to have been sexually assaulted compared to men. Undergraduate students (28\%) were more likely than postgraduates $(19 \%)$ to have been sexually harassed in a university setting in 2016 . The majority of these students (94\% and $87 \%$ ) did not make a formal report or complaint to their university. These data highlight the need for universities need to do more to build awareness and develop a culture of respect in a safe environment for learn- ing, with efforts being led by Vice-Chancellors and engaging all levels of the university. In addition to sexual harassment and assault, "everyday" or "casual" sexism towards women is harder to measure and often goes without correction. To raise awareness, encourage discussion and highlight the prevalence of everyday sexism in society and academia, a number of grass-roots projects have been set up. For example, "The Everyday Sexism Project" (https://everydaysexism.com, last access: 11 February 2020, Twitter: @EverydaySexism) and "Did This Really Happen" (https://didthisreallyhappen.net/, last access: 11 February 2020, Twitter: @team_dtrh; Bocher et al., 2020), which share stories of events that have happened.

Geoscience field-based courses or trips within undergraduate degrees might be attractive to many females but to others, who may not have previously spent much time outdoors or exploring remote areas, they can be intimidating. Issues such as access to suitable field gear, which can be more difficult to find for women or worrying about access to suitable toilet facilities on a remote field day can be enough to put someone off enrolling in a course with a field component (Greene et al., 2019; Giles et al., 2020). These issues are gradually being tackled by initiatives including pooled field gear for student hire, improved student briefings before and during fieldwork, including around menstruation in the field, and opportunities for students to confidentially raise concerns. The increased exposure of school-aged students to geoscience (including fieldwork) through programmes such as the UK's Girls into Geoscience (https://girlsintogeoscience.wordpress.com/, last access: 11 February 2020), and GeoBus (Brooke and Edgington, 2020) Programs, along with New Zealands' GeoCamp (https://www.gns.cri.nz/Home/Learning/GeoCamp, last access: 11 February 2020) are also actively addressing these matters.

One key issue lies in the retention of students through to postgraduate level and beyond. Data from both New Zealand 
and Australia show that women are less likely to enrol in postgraduate degrees (e.g., Ministry of Education, 2018b) and are more likely to drop out of a degree due to difficulties they may face with childcare and lack of paid maternity leave. In the United States of America, although over $40 \%$ of doctoral degrees in geosciences are now awarded to women, less than $10 \%$ of full-time professional positions in the field are held by women (Dutt et al., 2016).

Given the funding limitations and challenges faced by the higher education sector worldwide at present, as well as the general decline in geoscience undergraduate enrolments (Cohen, 2018), it becomes not only a matter of social justice but an economic incentive to universities to improve their retention, success and completion rates through inclusive practise (Naylor and Mifsud, 2019).

\subsection{Higher Education Research}

In the mid-1980s women comprised $20 \%$ of total academic staff (all disciplines) in Australian universities, yet they held only $6 \%$ of positions above senior lecturer. This has improved in the intervening 25 years, with women forming $44 \%$ of academic staff in 2014, and $31 \%$ of senior positions (Winchester and Browning, 2015). But there are still many challenges faced by women in academia. Women remain overrepresented in some disciplinary, teaching, and student support areas and significantly underrepresented in research (Winchester and Browning, 2015). As demonstrated by the data presented here, the male-dominated gender gap in senior roles persists in geosciences (Fig. 1).

\subsubsection{Academic staff}

The Australian Research Council (ARC) collected gender data by headcount for the first time during the ERA 2015 evaluation round. Gender information is now available for the 2015 and most recent 2018 evaluations, compiled within the "Gender and the Research Workforce" report (Australian Research Council, 2019). The proportion of female to male researchers in the Australian research workforce (all disciplines) has remained largely the same between the two evaluations, with $43 \%$ female researchers in 2015 and $44 \%$ female researchers in 2018. In terms of headcount, the number of male researchers increased by $11 \%$ while female researchers increased by $15 \%$ over the same period. However, the proportion of female to male researchers by discipline varies significantly.

Gender by two-digit Fields of Research (FoR) codes shows that Earth Sciences (FoR 04) and Environmental Sciences (FoR 05) have below the average female to male researcher ratio (44:56), with a ratio of $26: 74$ in Earth Sciences and 41:59 in Environmental Sciences, ranking 18th and 12th, respectively, in female:male researcher ratio out of the 22 two-digit Fields of Research considered in 2018 (Australian Research Council, 2019) (Fig. 1). Earth Science and Environmental Science FoRs saw a slight increase in the percentage of female researchers from 2015 to 2018: $25 \%$ to $26 \%$ in Earth Science and $39 \%$ to $41 \%$ in Environmental Sciences. Researchers by employment level and gender in the Environmental Science FoR shows the typical STEM pattern (Science in Australia Gender Equity, 2016) with similar numbers of staff at Levels A (Associate or Assistant Lecturer/Research Associate) and B (Lecturer/Research Fellow) but a disproportional loss of women relative to men as career stage progresses towards Level E (Professor), i.e., the open "scissor" pattern. However, within the Earth Science FoR 04 code, the number of female researchers is never in parity with male researchers, and the gap is largest at Level E (Fig. 1a). Gender by four-digit FoR code within the Earth Science and Environmental Science FoRs for Level A and Level E are shown for comparison in Fig. 2 (Australian Research Council, 2019). At Level A, females constitute less than $50 \%$ in all four-digit FoR code subdisciplines except for Ecological Applications and Environmental Science and Management. The subdisciplines of Atmospheric Sciences and Geophysics have the lowest percentage of females at Level A (Fig. 2a). At Professor Level (E), females make up between $4 \%$ to $26 \%$ of each subdiscipline, again with the Ecological Applications and Environmental Science and Management subdisciplines containing the most female professors $(26 \%$ and $23 \%$, respectively). Six out of the eleven subdisciplines have less than $10 \%$ females at Level E (Fig. 2b).

Figure 1c and $\mathrm{d}$ and Table $\mathrm{S} 1$ show new data presented in this study on the proportion of academic staff by gender at the institutional level compiled from publicly available university geoscience departmental or school websites in January 2020 for Australian and New Zealand universities, respectively. Data for the top three (QS- and Times Higher Education-ranked) Australian Universities are shown in Fig. 3 as an example of gender balance at institutional level. At country level, staff gender patterns in geoscience within the selected Australian and New Zealand universities presented in Table S1 show similarity to the ARC ERA 2018 pattern for Environmental Sciences, with relative parity of females and males by headcount at Levels A-B (Australia) and $\mathrm{A}-\mathrm{C}$ (New Zealand), but significant gender imbalance at Levels D and $\mathrm{E}$ in both countries, with more males than females in the more senior-level roles. Data available from the University of Papua New Guinea (PNG) and the University of the South Pacific (Fiji), show that there are no females at present at Levels D and E in either university (Table S1). At institutional level, females make up between $23 \%-52 \%$ of the total geoscience departmental or school staff in Australia, 26\%-39\% of the total staff in New Zealand, $29 \%$ of total staff at the University of Papua New Guinea and $18 \%$ (2 females to 9 males) at the University of the South Pacific (Table S1). University geoscience leadership roles, i.e., Head of Department or School, are male-dominated in Australia and New Zealand, with 12 males filling the 17 leadership roles in 
(a) Level A (associate lecturer)

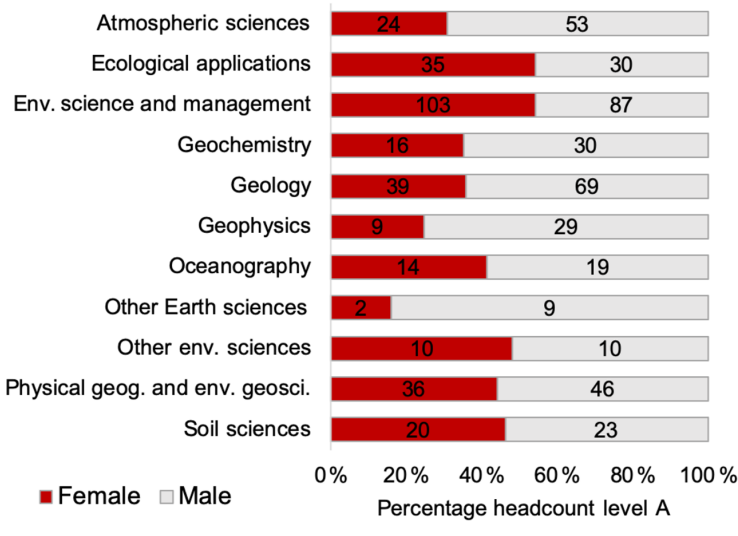

(b)

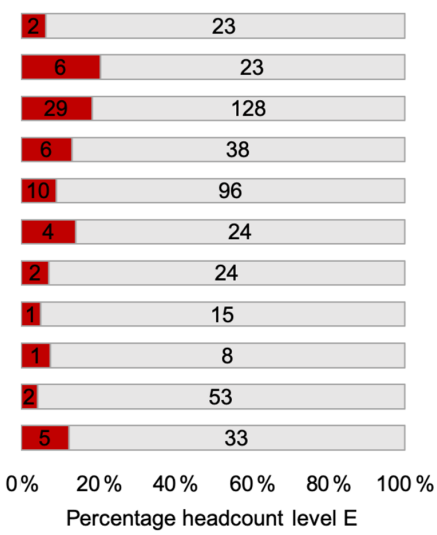

Figure 2. Percentage headcount by four-digit Field of Research (FoR) code within the two-digit Fields of Research for Earth Sciences (FoR 04) and Environmental Sciences (FoR 05) reported by the Australian Research Council (ARC) Excellence in Research for Australia (ERA) 2018 evaluation (Australian Research Council, 2019). (a) Percentage headcount at Level A (Associate or Assistant Lecturer/Research Associate). (b) Percentage headcount at Level E (Professor).
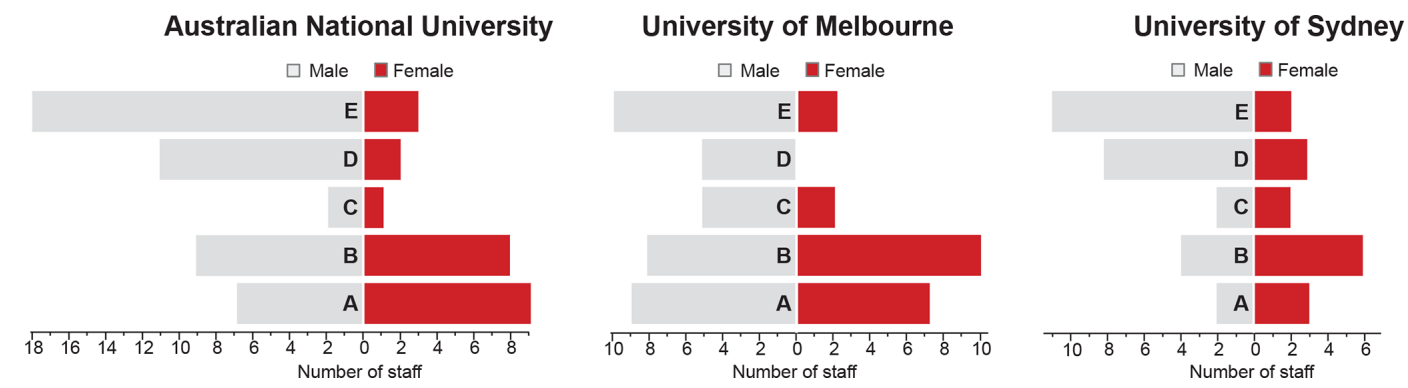

Figure 3. Staff profiles by headcount for three selected universities to exemplify high levels of gender inequity at Levels D (Associate Professor/Reader) and E (Professor) in geoscience in Australasian universities (see Table S1 for data of all the universities considered in this study).

Australia and 4 males occupying the 6 roles in New Zealand (Table S1).

\subsubsection{Research funding outcomes}

We were unable to find publicly available data on overall research gender profiles by employment level for geosciences or earth and environmental science disciplines for New Zealand (e.g., Royal Society Te Apārangi) for comparison. However, overall gender data for all disciplines are available for the Royal Society Te Apārangi Marsden Fund outcomes. In the 2019 funding round, $36.4 \%$ and $37.0 \%$ of investigators in research applications self-identified as female in the expression of interest and full application stages, respectively, with $37.5 \%$ of female investigators on proposals recommended for funding. Longitudinal data presented by the Royal Society Te Apārangi (2019) show that from 2000 to 2018, the percentage of Principal Investigators (PIs) identifying as female in the Marsden Fund expression of interest stage has been similar to the percentage of proposals with female as PIs funded. Exceptions are in 2008 and 2010, where a lower percentage of female PIs were funded relative to expressions of interest and in 2014, 2015 and 2018, where more females were funded. The percentage of female PIs submitting expressions of interest is generally increasing overtime from less than $20 \%$ in 2000 to around $35 \%$ in 2018 and 2019.

Gender insight into ARC funding outcomes in Australia is available across different schemes since 2002, and available for success rate by two-digit FoR by gender and year (Australian Research Council, 2020). Between 2002-2019, overall success rate by gender for key schemes such as the Discovery Projects scheme has ranged between $17.5 \%-30.1 \%$ for women compared to a slightly higher $18.1 \%-35.3 \%$ success rate for males. When all disciplines are considered, males were relatively more successful than women in every round of Discovery Projects since 2002, apart from 2018 and 2019. Success rates by two-digit FoR by gender by year for Earth Sciences and Environmental Sciences show no clear gender pattern, with variable female success rates from year to year relative to males (not shown). To improve gender equity and opportunity of all eligible researchers to partic- 
ipate in the Australian National Competitive Grants Program funding schemes the ARC's Equality Action Plan (ARC, 2018) was developed. Some of the present initiatives include: greater recognition of the impact of career disruptions such as those experienced as a result of parental leave and caring responsibilities in eligibility requirements and assessment of applications; two dedicated female fellowships in the ARC Australian Laureate Fellowship scheme; guidance for members of the ARC College of Experts, assessors and applicants with regard to performance relative opportunity; Centre-specific equity plan requirements for new ARC Centres of Excellence to implement; and continued monitoring, reporting and engagement in gender equity and equality matters.

Many factors likely contribute to gender inequity in the higher education workforce and funding outcomes. In addition to historic and continued gender-based barriers to female inclusion such as the lack of role models, caring responsibilities and harassment, clear bias and inequity surrounding fundamental aspects of research career progression (output and opportunity) are evident in STEM and Medical Science (e.g., Dutt et al., 2016). A cross-disciplinary bibliometric analysis of over 5 million Thomson Reuters Web of Science research papers and review articles with over 27 million authorships published between 2008-2012 (Larivière et al., 2013) shows men dominate scientific production by article outputs in almost all countries. The study also shows that women in dominant author positions on articles (in the most output productive countries) receive less citations than those by men in the same positions. Social network analysis (SNA) of Australian Research Council Linkage Infrastructure, Equipment and Facilities (ARC LIEF) grants (2008-17) and National Health and Medical Research Council (NHMRC) program grants (2003-18) showed that men mostly work with other men (Bogle, 2017). Data for NHMRC grants suggest that $84 \%$ of men that received a grant worked in men-only teams. In geosciences, an analysis of gender of authors and reviewers for American Geophysical Union (AGU) journals from 2012 to 2015 (Lerback and Hanson, 2017) showed that women reviewers were used less (proportionate to AGU membership representation), particularly by male editors, and females only made up $26 \%$ of submitting first authors. However, the acceptance rate for female first-authored papers was slightly higher $(61 \%)$ than male first authors $(57 \%)$. To address barriers to the career progression and the attrition of women in higher education a number of high-level and leadershipdriven initiatives have been developed that will be explored further in Sect. 8.

\section{Australasian geoscience government-run institutions}

In addition to major funding bodies, discipline-focused governmental institutions have a major role to play in setting expectations and leading by example for their respective in- dustry and university sectors. Therefore, leadership engagement and accountability in gender equity matters within geoscience-focused, government-run national organisations in Australasia, such as Geoscience Australia (GA) in Australia and Geological and Nuclear Science (GNS Science) in New Zealand are paramount to driving improvements in gender equity across the geoscience sector.

Australia's public sector geoscience organisation, Geoscience Australia, is visibly engaged in improving workplace diversity and inclusion, including gender equity. The present Chief Executive Officer (CEO), James Johnson, is a Male Champion of Change, part of a group of Australian male CEOs and Chairpersons that have made a commitment to ensuring the issue of women's representation in leadership is elevated on the national business agenda. The organisation made a written submission to the Australian Government's Women in STEM decadal plan, coordinated by the Australian Academy of Science and the Australian Academy of Technology and Engineering. Geoscience Australia has also been successful in their recent Science in Australia Gender Equity (SAGE) application for Bronze accreditation that was awarded in February 2020. The organisation recognised large gaps in workforce gender equity which led to the development of a Gender Strategy 2015-2018. This strategy was part of a number of disparate strategies and action plans which is now succeeded by a combined Diversity and Inclusion Strategy 2019-2022, of which gender is one of six identified diversity priorities. In 2018, $38.2 \%$ of GA employees identified as female (compared to $59 \%$ in the rest of the Australian Public Service, APS) with $23.7 \%$ female senior leaders (employment levels: Executive Level 2 and Senior Executive Service) compared to $45.6 \%$ in the rest of the APS (GA Diversity and Inclusion Strategy, 2019-2022). Actions taken are supported by HR but more widely through engagement with SAGE, and include: raising awareness of unconscious bias and gender roles (via an e-learning module with target of $35 \%$ staff completion), implementing SAGE actions that relate to employee engagement and ensuring that GA meets or exceeds Australian Guidelines with respect to gender identification (GA Diversity and Inclusion Strategy, 2019-2022, 2019). Their strategy and action plan is supported by a number of boards, networks and committees.

In New Zealand, GNS Science's Annual Report in 2019 showed that females make up $42 \%$ of the overall workforce at GNS Science and are underrepresented at the higher research and leadership levels. Males make up $57 \%$ of senior leadership roles and $62 \%$ of all research positions and females are overrepresented in lower level positions and support roles (e.g., females make up $69 \%$ of general support roles) (GNS Science, 2019). Despite the current overall underrepresentation of women, there have been significant improvements in gender balance at GNS Science over the last twenty years. In 1992, when the precursor to GNS Science (The Department of Scientific and Industrial Research) closed, only 5 females were on staff at the insti- 
tute, representing just $4 \%$ of the workforce (Nathan, 2020). The National Institute for Water and Atmospheric Research (NIWA) in New Zealand reported a male-dominated workforce in their 2019/20 Statement of Corporate Intent, with only $36 \%$ female staff (NIWA Taihoro Nukurangi, 2019b). Encouragingly, NIWA's 2017 Annual Report showed 51\% of new science staff hired were female and that this trend has continued (NIWA Taihoro Nukurangi, 2017, 2019b). Although there have been major improvements in the overall gender balance at geoscience-related Crown Research Institutes (CRIs) in New Zealand, there is still a huge amount of work to be done to increase the number of Māori women staff. In 1998, only $1.5 \%$ of employees across the seven CRIs identified as Māori women, with none in management positions, and only two scientists (Rust, 2015). The gender data presented here are overall totals, and as such are not necessarily representative of the true balance. For example, there is a significantly higher proportion of females on short-term or part-time contracts than males. A more accurate measure would be to look at the proportion of FTEs (full-time equivalents) held by males and females; however, such data are not currently available.

GNS Science's board of directors is currently $50 \% \mathrm{fe}-$ male (3 out of 6), with both the chair and deputy chairman positions held by women. NIWA's board of directors contains 4 out of 7 females; however, both the chair and deputy chairman positions are currently held by males. GNS Science's executive leadership team is also $50 \%$ female; however, there is one position currently vacant (at the time of writing) and the CEO is male. There are currently 18 staff at the level of principal scientist at GNS Science, of which only 3 are female. Only 2 out of 9 of NIWA's executive leadership team are female, with the CEO being male. NIWA's science leadership team is also male dominated, with only 3 females out of 13 staff at this level.

\section{Professional geoscience associations}

Professional associations in geoscience play a significant role in supporting the geoscience community across government, industry and academia and provide essential accreditation and recognition of experience for professional geoscientists, and recognition of excellence through awards that assist with employability and promotion of association members within their respective fields. In theory, membership of professional associations should reflect the gender balance of the industry and sectors they serve. However, membership from historically underrepresented groups such as women is likely influenced by current membership make-up and event participation, i.e., how "welcoming" the society is to the underrepresented group in question and therefore, professional societies may not engage and capture representative gender populations in the field. This "welcome" might be reflected outwards to the wider geoscience community through the gen- der balance of divisional committees and specialist groups, type and distribution of awards and gender balance of speakers at sponsored/associated/led conferences or events. To examine general association membership gender distribution and committee balance within professional geoscience associations we use the Geological Society of Australia as a case study with reference to other associations in Australia and New Zealand where data were easily accessible/publicly available.

The Geological Society of Australia (GSA) was established in 1952 with the aim to support, promote and advance earth sciences within the scientific and wider communities. The Society has divisions in Australian States and Territories and a number of specialist groups. The society publishes a peer-reviewed scientific journal "The Australian Journal of Earth Sciences", holds biennial conventions and specialist group meetings, produces a quarterly magazine, provides national and specialist group awards and professional accreditation. There have been 38 presidents of the GSA in total, including the current president. Of these, only four have been female, including the current and immediate past presidents (2016-2018). Others were Nelly Ludbrook (1968-1969) and Dorothy Hill (1973-1975). In August 2019 the GSA had 1689 members, $77 \%$ of which identified as male with a small increase in female membership between 2018 (19\%) and 2019 (23\%) (Table S2). Figure 4a shows that apart from the Northern Territory Division, which has a small total membership, females only constitute between $16-28 \%$ of each Division within Australia. Gender balance on GSA Divisional Committees is variable (Fig. 4b) but in general there are higher female:male committee member ratios compared to the female:male membership ratios of the Division they represent. The Queensland (QLD) Divisional Committee, has the lowest female to male ratio $(3: 16)$ but identical gender balance to the QLD divisional membership comprising $19 \%$ females $(38$ : 206). All other Divisions have a higher proportion of women relative to men on their committees, compared to the gender balance of their respective divisional membership. The Northern Territory Division (NT) Committee comprises $100 \%$ women. News South Wales (NSW) and Victoria (VIC) have more than $50 \%$ of their Committee comprised of women. Looking at the thirteen GSA Specialist Group Committees, four are absent of women and only three have $50 \%$ or more women (Fig. 4b, Table S2).

Similar male-dominated, gender distributions in membership are observed in other Australian professional associations. The Australian Institute of Geoscientists (AIG) 2017 membership profile and AIG's 2017 Australian Geoscientist Employment Survey data showed that males comprised $86 \%$ of AIG's fellows, members, graduates, students and retired members. Gender distribution varied by employment/career status with only $12 \%$ female AIG Members (with more than 5 years professional experience) and Fellows (with more than 15 years of professional experience), $29 \%$ female Graduate members (with less than five years' experience since grad- 

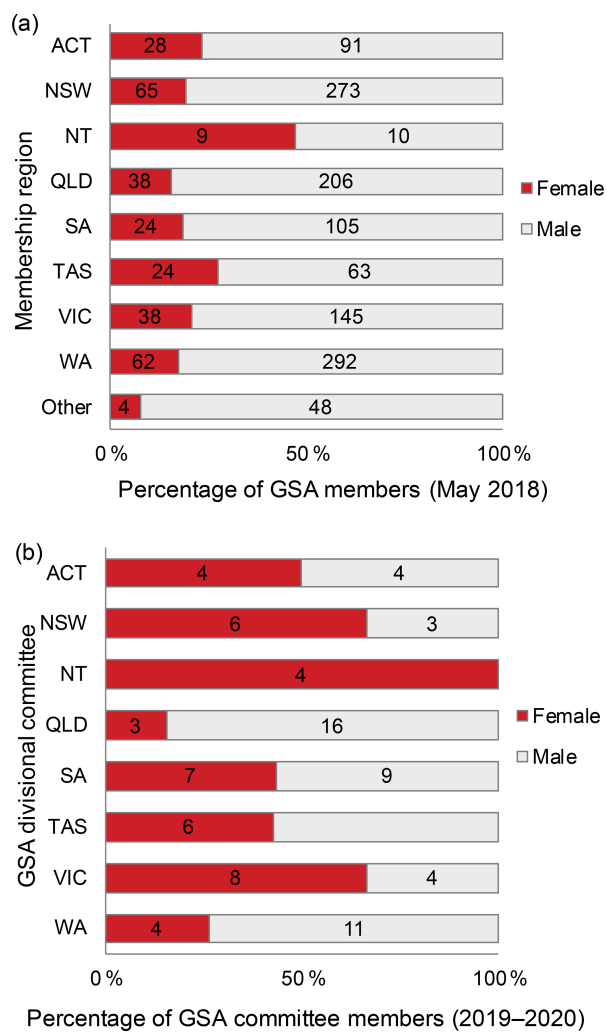

Figure 4. (a) Gender balance of members within the Geological Society of Australia (GSA) by State or Territory in May 2018. Australia Capital Territory (ACT), New South Wales (NSW), Northern Territory (NT), Queensland (QLD), South Australia (SA), Tasmania (TAS), Victoria (VIC), Western Australia (WA), Other: members located overseas. The Hunter Valley Branch is grouped within the NSW data. Membership numbers by headcount are displayed within the chart. (b) GSA Divisional Committee members by gender for the current period (2019-2020).

uation) and $34 \%$ of Student members were female (Waltho, 2017). We note that a small number of members elected to be identified as neither male nor female. The gender imbalance in AIG membership likely reflects the past dominance of men in the related industries in which many of the members work. AIG initiatives to support gender diversity and inclusion for carers involve members being able to retain involvement with AIG activities. Members can also request a membership subscription concession for up to three years while undertaking parental duties and are eligible for concessional registration for AIG events. AIG's Code of Ethics has also been reviewed to ensure the use of gender-neutral language.

If membership of these professional societies can be taken as a proxy for women's representation in Earth sciences in Australia (cf. Vila-Concejo et al., 2018) then women represent only around $15 \%-20 \%$ of the total workforce across academia, industry and government. With likely slightly greater representation of women in Earth Science in academia $(\sim 25 \%$ indicated by the ARC Earth Science FoR code). From an employment survey in 2018 (Waltho, 2019), AIG estimated that $85 \%$ of Australian geoscientists are men, with fewer women than men working in the mineral exploration sector compared to other sectors. This may be due to the non family-friendly aspects of being away from home in remote areas for significant periods of time. The 2018 survey showed that there were more women than men working in metalliferous mining, energy exploration, government, engineering geology, industrial minerals and environment sectors (Waltho, 2019). An assessment of gender representation in the membership of six worldwide coastal geoscience and engineering societies showed female representation varied between $15 \%$ to $45 \%$ (Vila-Concejo et al., 2018).

In New Zealand, the Geoscience Society of New Zealand (GSNZ) supports the advancement of geosciences in New Zealand. There are currently more than 700 members, an elected national committee, eight branches and a number of subcommittees and special interest groups. Membership is open to anyone with an interest in geosciences. The Society holds a conference in a different part of New Zealand every year, presents annual awards, and publishes a newsletter every four months. The current national committee for GSNZ is made up of 6 female and 9 male members, with a male president and female vice-president (http://www.gsnz. org.nz/information/national-committee-i-2.html, last access: 11 February 2020). There are currently no special interest groups or subcommittees under the GSNZ led by females. Four out of fourteen on the sub-committee for the Fossil Record Electronic Database (FRED) are female, and three out of ten on the sub-committee for Geoheritage are female.

\section{Professional association awards}

An important service that professional associations provide is external recognition through awards that promote standards of high quality. Awards provide a multitude of career benefits by increasing the external visibility and credibility of award recipients, important in promotion, job and research grant applications. Therefore, the recognition of women in such awards is vital for the retention and career progression of women in the workforce. The GSA and GSNZ provide a number of national or general awards as well as other specialists awards or grants. An assessment of gender representation in national and general GSA and GSNZ awards since their respective establishment is displayed in Fig. 5 and presented in Tables 1 and S3. Of the five national GSA awards that have been awarded to 47 people, only two (4\%) have been awarded to women, in 2002 and 2016. Three of the five awards have never been presented to a woman. This percentage is well below the current representation of female members in the society of $23 \%$ (Table S2). Table S3 also shows that all past GSA awards named in honour of a person are all named in honour of men. In recognition of the need to do more to support women and those at early-mid career stages, the GSA has recently established two new awards: 


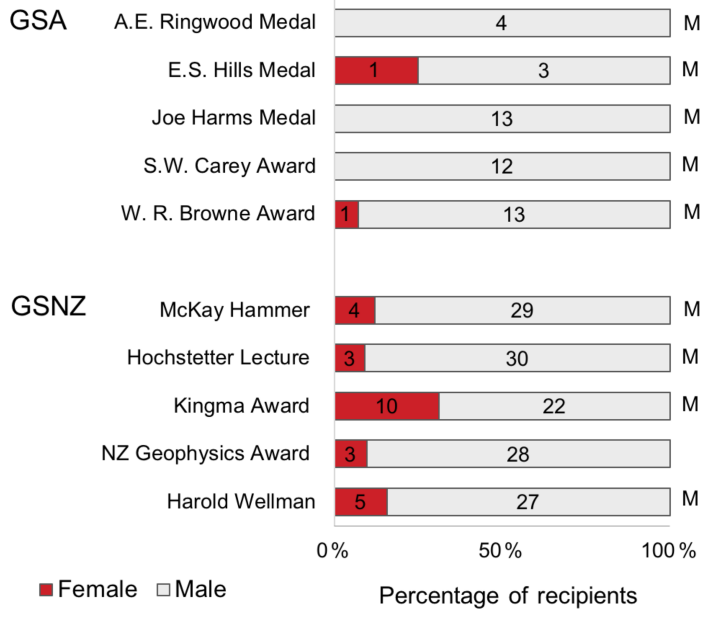

Figure 5. Gender representation in GSA and GSNZ national awards by proportion with the number of recipients indicated. The letter on the right-hand side indicates whether the award is named in honour of a male ("M") or female ("F"). Note that none of these awards were named in honour of a woman. Data taken from the respective society websites for GSNZ (https://www.gsnz.org.nz/awards-and-recognition/ past-award-recipients/, last access: 9 September 2020) and GSA (https://www.gsa.org.au/Public/Recognition_and_Awards/ National_Awards/Public/Recognition_and_Awards/Awards.aspx? hkey $=\mathrm{d} 9641 \mathrm{bb} 1-\mathrm{ff9c}-4 \mathrm{f} 5 \mathrm{e}-813 \mathrm{c}-7 \mathrm{eb063a80958}$, last access: 24 Feburary 2020).

the Garry Davidson award and the Beryl Nashar GSA medal, which will be awarded for the first time at the 2021 Australian Earth Sciences Convention. The Beryl Nashar medal is the first geoscience award in Australia or New Zealand to be named in honour of a female scientist and serves to recognise the achievements of female Australian geoscientists at a national level.

The five GSNZ awards considered show, on average, higher female representation in awardees than the GSA awards listed, with 25 women receiving awards out of 136 total awards (18\%) but this is still far from equity. The highest number of female awardees for an individual award (45\%) was for the Kingama Award which is presented to the most outstanding New Zealand Earth Science technician of that year (Tables 1 and S3). The GSNZ awards detailed in Table S3 are all also named after or in honour of men (where applicable).

Gender inequity in awards is not unique to GSA and GSNZ. For example, the Geochemical Society's V. M. Goldschmidt award recognising major achievements in geochemistry or cosmochemistry has been awarded annually since 1972 with only four women receiving the award (in 2006, 2015, 2016 and 2017) out of a total of 48 awards presented (https://www.geochemsoc.org/ honors/awards/vmgoldschmidtaward, last access: 24 Feburary 2020).
Most award processes involve nomination, panel assessment and selection. Implicit biases impacting women and other underrepresented groups in the latter two stages can be improved with unconscious bias training, gender balance on selection committees and improved consideration of career disruptions. Improving the gender balance in nominations is seen as one of the largest hurdles to overcome in order to improve gender equity in awards (Mukasa, 2009; Jaynes et al., 2019). Solutions include active solicitation of eligible and competitive women by the society committee and its members. Towards this goal the \#NominateHer movement is being highlighted by organisations such as Science and Technology Australia to "celebrate inspiring, capable women across the country" in Australia.

\section{The role of women-focused geoscience networks}

When considering solutions to gender inequity in the workforce it may seem contradictory at first to purposefully establish women-focused networks where membership is dominantly of one gender i.e., highly gender imbalanced. However, women-focused networks provide a safe place to share experiences and advice specific to the challenges women face in the workforce. A collective of like-minded people with the same goal to increase gender equity and opportunities and career progression for women also provides a stronger voice to advocate for change. A study looking at the relationship between graduate students' social networks and placement into leadership positions suggested that women achieving highplacing leadership roles had broad networks (like men did) but additionally, had a close circle of other women (Yang et al., 2019).

In geosciences, a number of international, national and institutional women-focused geoscience networks have been established with a variety of initiatives that include mentorship programs, networking events, online resources, awards and grants, building role models and increasing the visibility of women in geoscience (Table 2). Membership is free for some but others require subscriptions and networks are largely inclusive, meaning that members beyond women in geoscience careers are welcome. The international Women in Mining (WiM) network (https://internationalwim.org/, last access: 11 February 2020) is one of the largest with over 10000 members in over 100 countries and supporting over 50 more local independent WiM associations including those in Australia and New Zealand (Table 2). The international, but U.S.-focused, Earth Science Women's Network (ESWN) began informally in 2002 and officially launched as a nonprofit entity in 2014 (https://eswnonline.org/, last access: 7 February 2020). The network is dominated by graduate students and postdoctoral researchers and aims to "promote career development, build community, provide informal mentoring and support, and facilitate professional collaboration amongst women scientists". One of the most recently es- 


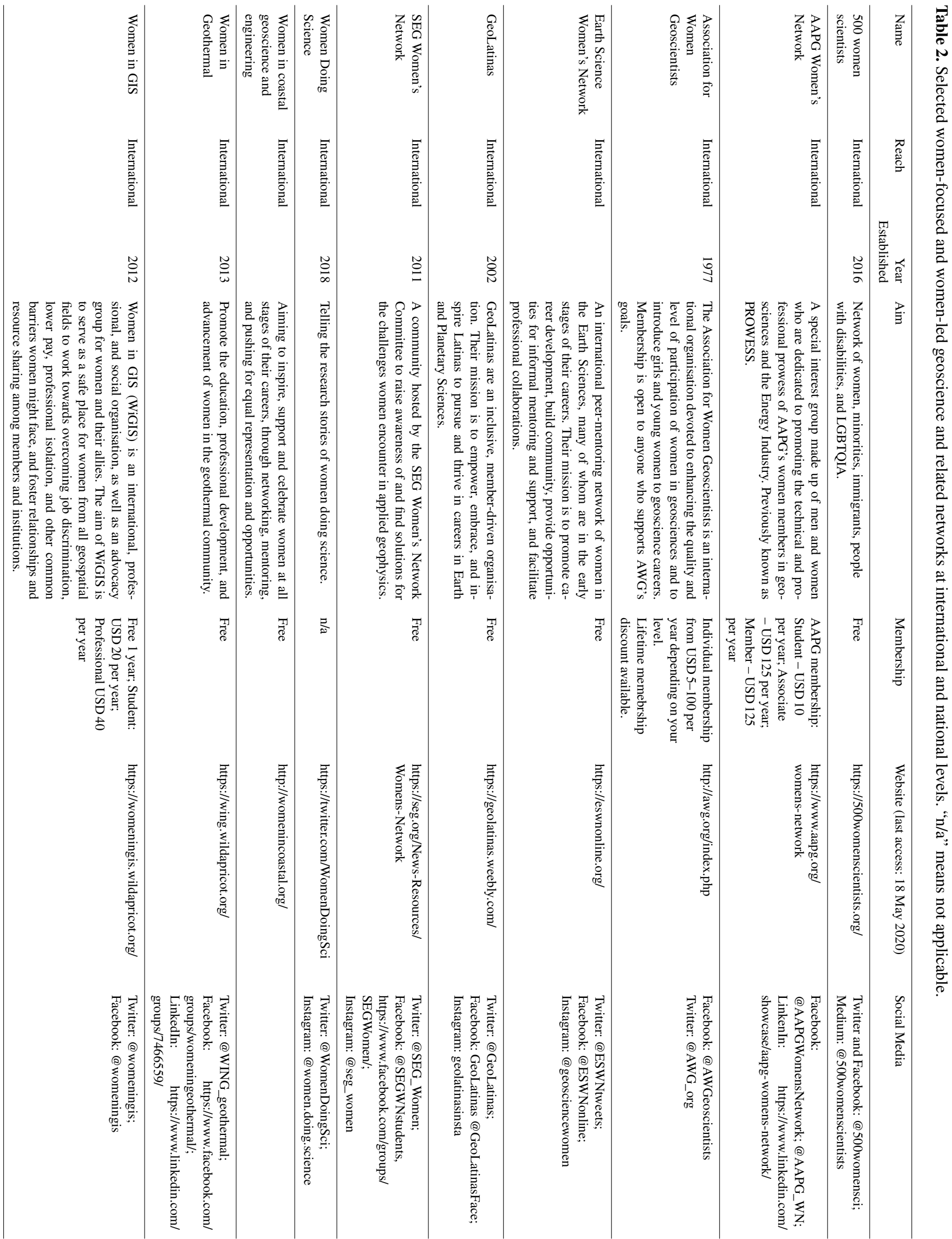




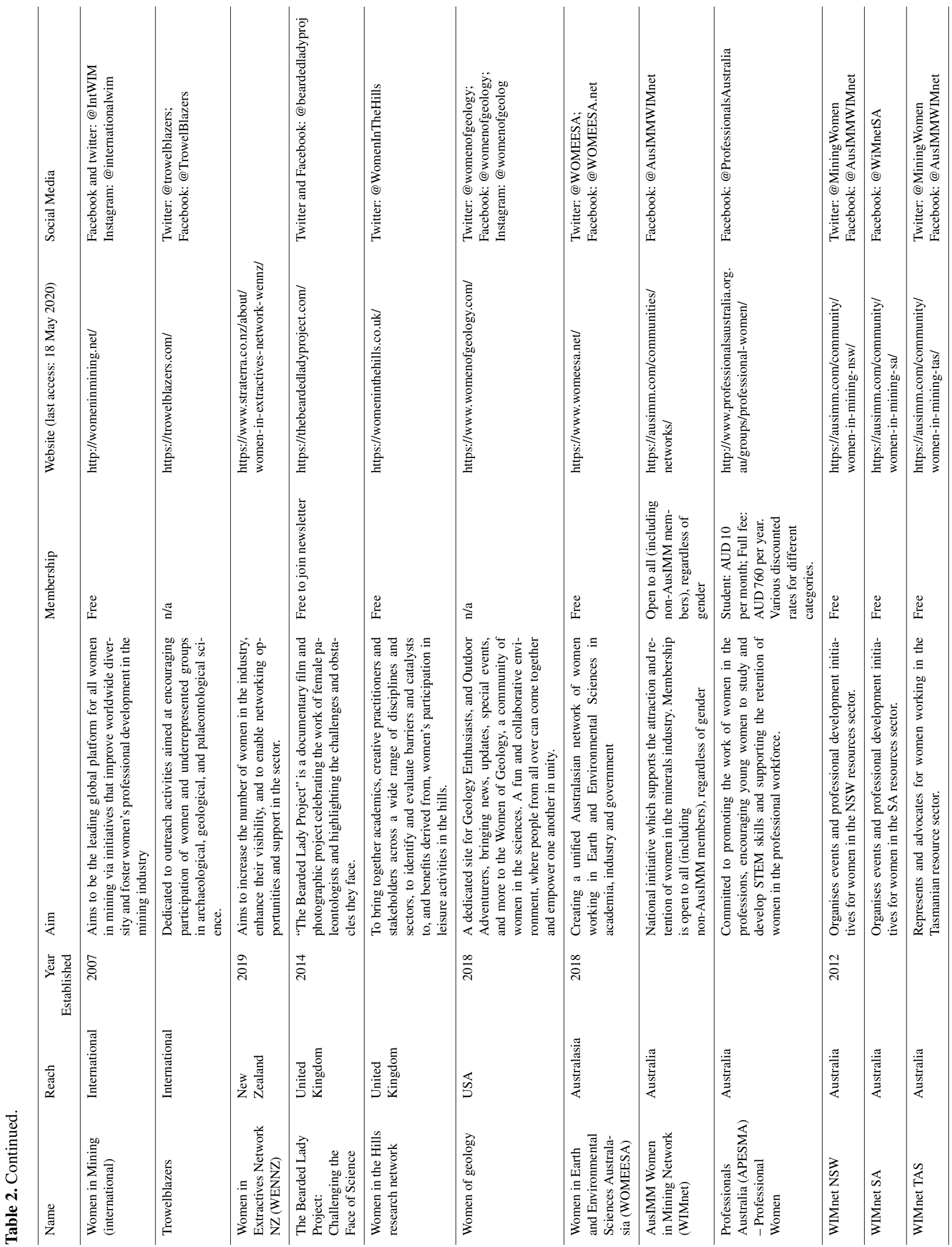




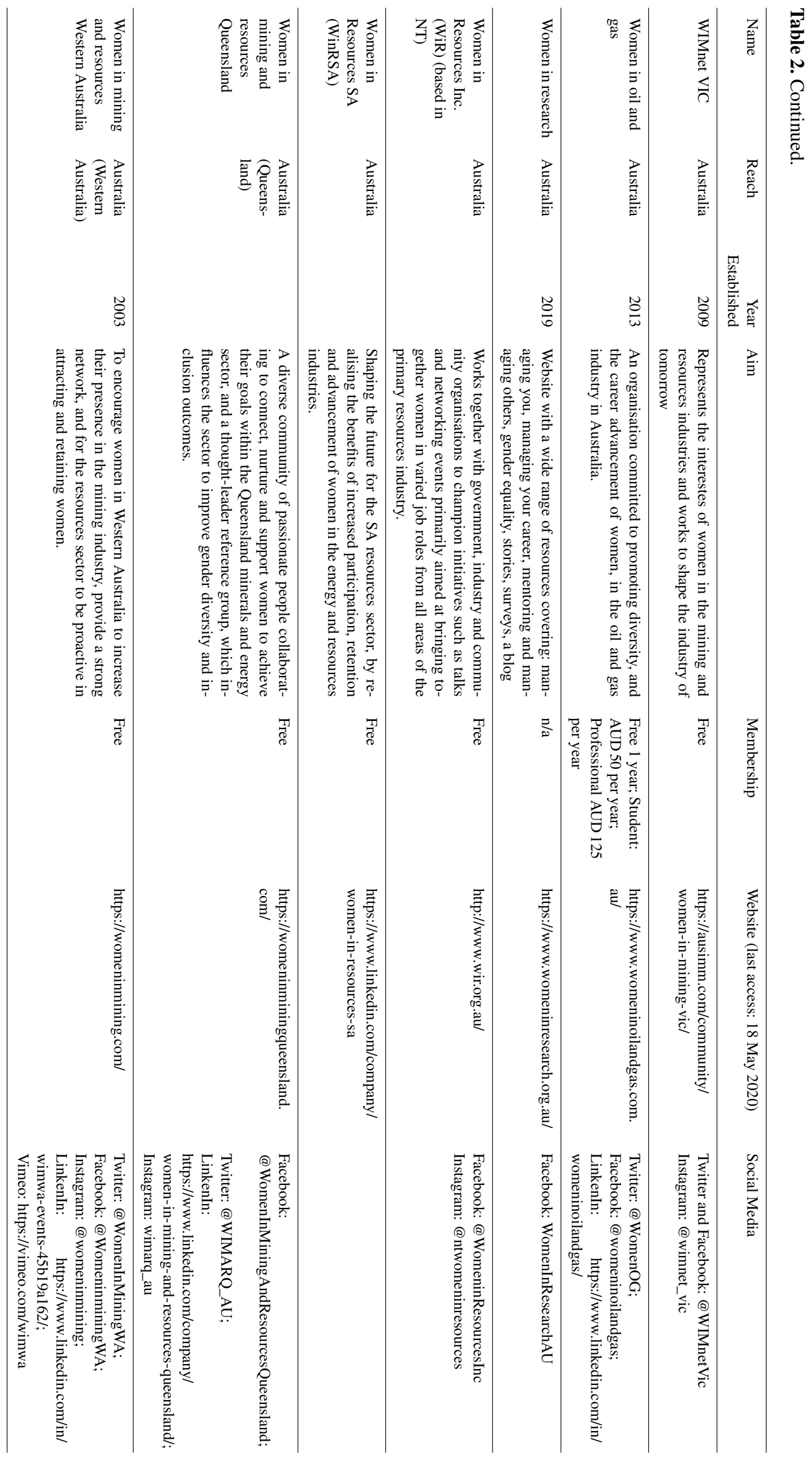


tablished, international geoscience women's network is GeoLatinas, an inclusive, member-driven network aiming to "embrace, empower and inspire Latinas to pursue and thrive in careers in Earth and Planetary Sciences". GeoLatinas was launched in 2019 and currently has 156 members in 24 countries (at 7 February 2020; https://geolatinas.weebly.com/, last access: 7 February 2020).

Within Australasia, the majority of women-focused geoscience networks serve a particular niche and are industryfocused, e.g., The Australasian Institute of Mining and Metallurgy (AusIMM) Women in Mining Network (WIMnet) with state groups in NSW, SA, TAS and VIC, Women in Mining Western Australia (WIMWA), Women in Mining New Zealand, Women in Oil and Gas, and Women in Resources (WiR) (see Table 2), providing networking events, mentoring programs and annual summits. In 2019, The Women in Sustainable Development Program (WiSP) was launched in 2019 by the Geoscience, Energy and Maritime Division (GEM) of The Pacific Community (SPC), focused on career development, mentoring and leadership of women in the Pacific Islands and Territories. To fill the void of women-focused geoscience networks at regional, national and international level within Australasian countries for women in academia and governmental organisations, the Women in Earth and Environmental Sciences Australasia (WOMEESA) network was launched on International Women's Day in March 2018. WOMEESA's overall goal is to create a unified Australasian network of women working in Earth and Environmental Sciences across academia, government and industry, to encourage networking and increased collaboration between sectors. The idea for the network arose during the inaugural Dorothy Hill Women in Earth Science Symposium held at the University of Queensland in November 2017. A symposium that provided a platform for career development for the geoscience community in Australia, with a particular focus on celebrating and promoting female geoscientists across different sectors. In May 2020, WOMEESA had 499 members from 14 countries (several outside of Australasia), $94 \%$ of which identified as female. Membership is comprised of women at a range of career stages: Undergraduate Student (13\%), Masters Student (8\%), PhD Student (20\%) Early Career $(24 \%)$, Mid-Career $(23 \%)$, More than 15 years of experience $(9 \%)$ and Other ( $3 \%)$. WOMEESA is dominated by members from academia, who constitute $59 \%$ of the membership, with $16 \%$ industry employed members, $14 \%$ government employed members and $11 \%$ other (Fig. 6). The large number of academic members likely reflecting the lack of existing women-focused networks at a regional or national level in academia in Australasia.

A survey of WOMEESA members in March-April 2018 (120 respondents) indicated that members were most interested in networking and scholarship/grant opportunities (over $90 \%$ of respondents), mentoring programs (80\% of respondents), and conferences and awards ( $\sim 70 \%$ of respondents). The survey also highlighted that only $33 \%$ of respon-

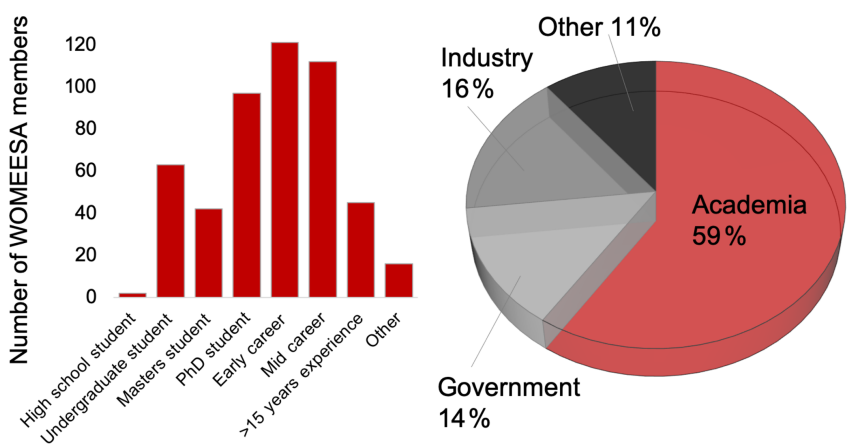

Figure 6. Career stage and area of employment of the 458 WOMEESA members at January 2020.

dents had a formal mentor, $28 \%$ had no mentor at the time of the survey and $71 \%$ were not a mentor themselves. The limited mentee roles of members indicates that more could be done through mentoring to support the career progression and retention of women, and feed the leadership pipeline of women in geosciences in Australasia.

WOMEESA has led a number of initiatives to date, focused firstly on networking and mentoring aspects via a series of formal workshops and informal social events. Its online blog and member spotlight features help to create role models, share experiences and provide useful resources. WOMEESA Team members successfully advocated for onsite childcare provision at the Australian Geoscience Council Convention (AGCC) in 2018. WOMEESA collaborated with the Australian Society for Exploration Geophysicists (ASEG) in October 2018 to provide a joint written submission to the Australian Government's Women in STEM decadal plan. WOMEESA has designed do-it-yourself business cards to facilitate networking of WOMEESA members at conferences, particularly for postgraduate students and those in the early stages of their careers who might not have access to business cards. WOMEESA hand-drawn baby onesies were also created to raise awareness of the need for onsite childcare at conferences.

While there are fewer women than men in academia overall, the proportion of women on conference panels and as invited speakers is disproportionately low (e.g., Vila-Concejo et al., 2018). As gender equity has become of greater concern in universities, conference and workshop organisers commonly face criticism about the gender imbalance of invited keynote speakers and panellists who are often maledominated, especially since attendees are commonly close to gender parity (e.g., @ManelWatchAU on Twitter). Organisers frequently report that they tried to get female representation but failed, or else that there are no women at a suitable level within the discipline. Disproportionate representation of women is also seen in applicants for academic jobs, where the proportion of female applicants is commonly $<30 \%$ and sometimes $<10 \%$ (Ceci et al., 2014). Chairs of selection committees are sometimes asked to improve diversity of their 
applicant lists, to which they often reply that they have exhausted their networks and known potential applicants but the women are just not there.

An outcome of a 2018 WOMEESA AGCC workshop was the proposal to build a searchable database of women working in Earth and Environmental Sciences in Australasia to increase the visibility of women and assist potential employers, conference and workshop organisers, seminar program chairs, the media etc. to find suitable women looking for particular opportunities. Therefore, in 2019, a database of earth and environmental women scientists was created. Atmospheric scientists were also included in the database due to the environmental and climate focus of their work, as well as their interest in being involved. As of May 2020, there were 238 women listed in the database (Table S4). At present the database is downloadable from the WOMEESA website as a spreadsheet (https://www.womeesa.net/ database, last access: 18 May 2020). WOMEESA suggests that the database be adopted as a consultancy tool employed routinely in university departments, industry and government as part of the process of organising a conference or advertising a position. In 2019, the Australian Academy of Science launched STEM Women (https://www.stemwomen.org.au/, last access: 11 February 2020), a similar database to WOMEESA's providing women looking for a range of careerprogressive opportunities and providing additional visibility for Australian women geoscientists.

In addition to top-down and institution-driven initiatives, women-focused networks can play a key role in providing a supportive networking environment, that indirectly and directly assist career development and retention of women in the geoscience workforce, along with providing a unified voice to advocate to improve gender equity. However, few data are publicly available measuring the impact of women's geoscience networks across Australasia.

\section{Initiatives and solutions to addressing gender inequity in Australasian STEM and geoscience fields}

This study highlights that systemic, societal changes and improved laws are needed in several Australasian countries to protect and support women. These societal changes are likely to take significant time to achieve, such as elimination of sexual harassment and gender-based violence in the community and workplace, greater access to and take up of parental leave and flexible work for men in the workplace, genderequal share of household work and carer responsibilities, and the removal of conscious and unconscious biases. Without these changes gender equity in STEM and geoscience will be harder to achieve across Australasia as a whole.

In recent years, there have been a large number of initiatives aimed at improving gender equity in the STEM workforce and in leadership roles. A few examples from Australia and New Zealand are provided below as a means to share current approaches and practices to stimulate further discussion and ideas. The path to lasting change in gender equity starts with the commitment and accountability of leaders in creating gender inclusive workplaces. Examples of innovative leader-driven initiatives to address gender equity and the career advancement of women in Australasia include the formation of the Male Champions for Change (MCC) to engage influential male leaders to take action on gender inequity that achieves change. The MCC initially formed in 2010 with eight Australian leaders and now comprises fifteen groups and over 230 leaders in Australia. The MCC and Chief Executive Women, a group of women leaders striving to enable other women leaders (founded in 1985), joined forces to develop The Leadership Shadow model (Australian Human Rights Commission, 2014). The model is designed to assist every leader to become a champion of diversity and inclusion by providing a practical framework to evaluate their own actions and impact. It consists of four elements: (1) What I say, (2) How I act, (3) What I prioritise, and (4) How I measure, and suggests actions and behaviours to improve gender balance within organisations.

In alignment with the Workplace Gender Equality Act (Australian Government, 2012) in Australia, organisations can apply for the WGEA Employer of Choice for Gender Equality (EOCGE) citation (that replaces the earlier "Employer of Choice for Women" citation), which is designed to encourage, recognise and promote active commitment to achieving gender equality in Australian workplaces. The WGEA EOCGE 2018-19 round focused on recognising organisations strengthening their accountability in regard to their formal gender equality strategy. 2018-19 EOCGE citation holders included 19 universities and university-related entities (13\%) out of a record number 141 organisations with 26 first-time recipients. The 2019-2020 round which placed greater emphasis on accountability, evidence of outcomes and internal reporting in the eligibility criteria and recognised 119 organisations, with 14 first-time recipients and included 13 universities and university-related entities (11\%) plus one mining organisation. A recent study by the University of Queensland and the WGEA report that employers with citations are closing their gender pay gap at a faster rate $(9.2 \%$ drop) than other reporting organisations $(3.7 \%$ gap drop) in the period 2013-2014 to 2017-2018 (Fitzsimmons et al., 2020). The report also shows that organisations with EOCGE citations have higher representation of women at all levels of management. Although, it is not entirely an inclusive scheme with an annual fee at the time of writing of AUD 1950.

Within the higher education and research sector, major advances in the removal of structural barriers to gender equity are being made through the Universities Australia Executive Women's Group (UAEW) established in 1994 (formally Australian Colloquium for Senior Women Executives in Higher Education) that address issues related to gender imbalance of academic and professional women in se- 
nior leadership roles within universities through a rolling action plan. Progress is also being made to reduce gender inequity through engagement with initiatives such as the Athena SWAN Charter (UK and Ireland), and Australia's Athena SWAN-based, Science in Australia Gender Equity (SAGE) pilot program partnered by the Australian Academy of Science and the Australian Academy of Technology and Engineering. Such schemes require commitment from university and research leaders to support and resource their respective institutes to lead an evidence-based evaluation of policy, practices and cultural change to drive gender equity and diversity. Examples of systemic changes achieved through engagement in these programs include: the overhaul of academic promotion schemes to create more flexible career pathways, the implementation of improved parental leave and flexible work policies and procedures, the establishment of new academic job types, and unconscious bias training for hiring panels. In the UK, change to a more positive culture in medical sciences is attributed to policy introduction and clear expectations by the National Institute for Health Research (NIHR) linking research funding support to Athena SWAN commitment and outcomes (Ovseiko et al., 2019). Complementary to the SAGE pilot program in Australia, The Women in STEM Decadal Plan is creating a 10-year road map to lead to a sustained increase in participation and retention of girls and women in STEM subjects and careers. The Decadal Plan was launched in April 2019 by the Australian Academy of Science in collaboration with the Australian Academy of Technology and Engineering at the request of the Australian Government (Australian Academy of Science, 2019). The initiative has engaged diverse stakeholders in national consultation via written submissions, interviews and workshops.

In 2016, a national working group for diversity and equity decided not to adopt the Athena SWAN model within the research community/tertiary sector to address gender inequity in New Zealand. In 2018, The Royal Society Te Apārangi set up Te Kauhuahua as an advisory group who monitor progress on commitments made in the Society's diversity policy. In New Zealand, current national initiatives focus on empowering and supporting women through The New Zealand Universities Women in Leadership Program (NZUWiL), which constitutes residential programs designed to support academic and professional current and future women leaders within the Tertiary Sector. The New Zealand Association for Women in the Sciences (AWIS), was founded in 1985 to address conscious and unconscious bias, develop careers and ensure work-life balance through advocacy, networking and learning events. The association also offers awards and scholarships for women in science.

Cohen (2018) summarises some of the changes that need to be made in order to encourage more women to participate in STEM subjects at all levels of education. Increasing the visibility of women is one of the most significant changes that can be implemented across the board to help combat stereotypical views of what a scientist looks like (Miller et al., 2018). A study in 2018 found that the numbers of students pursuing a career in geosciences approximately doubled for every role model they identified (Hernandez et al., 2018). It is worth noting that role models in science do not necessarily have to be gender-matched, studies have shown that it is more important that the scientists are able to establish connections, show passion for their work, convey the "wow" factor and be innate teachers (Farland-Smith, 2014). To increase female STEM role models in Australia and inspire the next generation of scientists, Science and Technology Australia created the Superstars of STEM Program in 2017. The program selects a number of female scientists, technologists and engineers from variety of ethnic backgrounds that are working in STEM-careers across academia, industry and government. The Superstars visit schools across Australia to give school talks, community events and engage directly with the students to encourage them to consider a science career.

Quotas or women-only employment positions are seen as one solution to reduce gender inequity but often encounter backlash from both women and men, as men feel excluded and women wish to be employed based on their merit. Women-only academic STEM and geoscience positions were recently advertised at the University of Adelaide and the University of Tasmania as a direct approach to address gender inequity in staffing profile. Such exclusive positions could likely be avoided if universities were proactive in cultivating the initial application pool by accessing databases of women, such as the WOMEESA and STEM Women databases to search for suitably qualified applicants and invite them to apply. Institutions should also ensure to use gender-neutral language when writing job advertisements to avoid gender bias (Government of South Australia, 2017).

\section{Conclusions and recommendations}

Despite the presence of national policies and strategies on gender equity throughout many Australasian countries, women continue to face significant discrimination and harassment within society and the workplace. Women remain underrepresented in traditional male-dominated STEM careers including geoscience across the region. Achievement of gender equity will require the continued commitment and accountability from all stakeholders and at all levels to make change, in particular from leadership and by government. The barriers to women's career progression and retainment are numerous and there are a multitude of initiatives exemplified at different levels throughout Australasia striving to make a difference through innovative solutions. Mechanisms now need to be in place to measure the impact of gender equity initiatives through data collection and surveys to assess which approaches are most effective and sustainable in increasing gender equity (e.g., Kingsley, 2020). This can be challenging, as the impact is likely not immediately measur- 
able, but change occurs directly and indirectly over many years. Sharing best practise of evidence-based approaches that have had demonstrated positive outcomes will be beneficial, like that undertaken through the engagement of higher education and research institutions with the SAGE Pilot in Australia. Recent assessment of the impact of the WGEA EOCGE citation has shown that engagement in initiatives in which equity and equality gender policies and strategies are embedded at high levels of organisations that make a clear commitment to change leads to more rapid improvements in gender equity. A recent paper by Vila-Concejo et al. (2018) provided recommendation of seven practical steps to improve gender equity in coastal geoscience and engineering that are also applicable to geosciences more broadly: "(1) Advocate for more women in prestige roles; (2) Promote high-achieving females; (3) Create awareness of gender bias; (4) Speak up; (5) Get better support for return to work; (6) Redefine success; and, (7) Encourage more women to enter the discipline at a young age.". Further recommendations to improve gender equity in geosciences in Australasia are provided below.

\subsection{Greater data needed on why women leave geosciences in Australasia}

This study presents a snapshot of current gender inequity in geoscience in Australasia within government, academia and professional associations. Despite a good understanding of the barriers to women in STEM careers, there is relatively little data available from women in geosciences in Australasia who have left the system (the "leaky pipe") on why they left. Quantitative and qualitative surveys providing this information would help to focus initiatives to improve the retention and career progression of women in Australasia.

\subsection{Rethinking recognition}

The new awards created by GSA will assist in increasing the number of women award recipients and we recommend that all professional associations in geosciences should re-think how we provide recognition and reward excellence to improve diversity and equity in awardees, learning from the approaches taken by other disciplines on this matter (e.g., Royal Society of Chemistry, 2019).

\subsection{Raise the visibility of women through open-access databases}

The WOMEESA Database of Women in Earth, Environmental and Atmospheric Sciences provides an important resource to address a number of gender inequity and inequality issues in Australasia, such as poor gender balance in invited speakers and panellists. It also serves to address reliance on the same women to fulfil roles and reduce service workload overload by increasing the visibility of other women with similar skills and experience. The database also addresses the un- derrepresentation of women in STEM in the media by providing a list of women looking for particular media and outreach opportunities. We recommend greater promotion and use of such databases by geoscience governmental organisations, professional societies and university schools and departments in the region.

\subsection{Greater promotion of the value of mentoring and provision of inclusive mentoring programs}

The lack of WOMEESA members without formal or informal mentors identifies that we need to be doing more within geosciences to ensure that all women have access to mentors (male or female). Many mentoring systems are designed "top-down" with the responsibility of the mentor role falling on the limited number of women in higher level positions, which also produces additional service-gendered stress on women. Furthermore, over the last decade the workplace environment has changed significantly for women, and so the potential generational gap between mentor and mentee may mean that the challenges faced by mentors in the past are not as relevant to younger mentees today. We suggest to remove the often "default" hierarchal structure of mentoring programs and promote horizontal mentoring (e.g., Karukstis, 2010; McDaugall and Beattie, 1997). Mentors and mentees/mentors could be matched with 2 to 4 others based on explicit skills or experiences that mentors can offer or, that mentees are looking for, regardless of career status. For example, a PhD student may have worked for 6 years in the mining industry before commencing $\mathrm{PhD}$ research in academia and so be excluded as a mentor in normal mentoring programs despite having significant experience in industry. In this way, by each mentor/mentee being linked to several others, there is potential for greater network expansion for the individuals.

\subsection{Eliminate and actively address everyday sexism and harassment in geosciences: Field trip code of conducts}

Awareness of casual sexism in geoscience is increasing via innovative, grassroots-approaches such as the "Did This Really Happen" initiative. However, more needs to be done to address sexual harassment and assault during fieldwork, an important component of most geoscience degrees and careers, which predominantly occurs against women. We recommend an across sector introduction of specific fieldwork codes of conduct, in addition to standard organisational conduct codes, detailing clearly what constitutes misconduct and how to make an anonymous complaint (to people in addition to the field trip staff) if misconduct is experienced. All field trip attendees, including staff and management, should sign an agreement on every field trip with clear and firm consequences if the agreement is breached. 


\subsection{Engage all the geoscience community to create sustainable change}

Greater support and engagement from males in addressing gender inequity is a key component in creating and fostering long term, sustainable change (e.g., Male Champions of Change). The success of the initiatives and recommendations outlined in this paper is dependent in the long term on the engagement of the wider geoscientific community. Therefore, we recommend increased gender equity-focused initiatives that aim to engage diverse audiences and embed gender equity targets through policy at all levels of management. In this study, we have concentrated on gender, in part due to the availability of data. We recommend future studies also focus on intersectionality (e.g., Núñez et al., 2020), for which there is limited data currently available.

Data availability. Data compiled by the authors from publicly available websites in this study are available in the Tables S1-S4. All other data from third parties are available online from the indicated sources. WOMEESA membership data is not publicly available but can be requested from the lead author, Heather K. Handley.

Supplement. The supplement related to this article is available online at: https://doi.org/10.5194/adgeo-53-205-2020-supplement.

Author contributions. HKH provided the initial concept for the study which was further developed by all co-authors. Table 2 was compiled by SK, MF, HKH, and TU. All authors contributed to data collection in the production of Table S1. AP and CT assisted in acquisition and compilation of gender data from the Geological Society of Australia provided in Table $\mathrm{S} 2$. JH and HKH compiled the award data in Table S3. MF and HKH produced Table S4. HKH led the preparation and writing of the manuscript with input and edits from all co-authors. SK, JH and HKH prepared the manuscript figures. JH, $\mathrm{HKH}$ and $\mathrm{AF}$ compiled and formatted the references.

Competing interests. All authors are members of the WOMEESA network and employees of their respective affiliation as provided. Heather K. Handley, Teresa Ubide, Sandra McLaren, Jess Hillman, Anna Petts, April Foote, Sarah Kachovich and Jemma Purandare are past or present WOMEESA committee members. Heather K. Handley, Teresa Ubide, Sandra McLaren have received past or present research funding from the ARC. Jess Hillman is a member of the GSNZ. Heather K. Handley, Teresa Ubide, Anna Petts, Caroline Tiddy, Sandra McLaren are members of the GSA. Caroline Tiddy and Anna Petts are GSA committee members. WOMEESA has a collaborative relationship with GeoLatinas and has been supported by the GSA in the catering of some events. Teresa Ubide and Sarah Kachovich were on the organising committee of one or both past Dorothy Hill Women in Earth Science Symposiums (2017 and 2019).
Special issue statement. This article is part of the special issue " $\mathrm{Di}$ versity and equality in the geosciences (EGU2019 EOS6.1 \& US4, AGU2018 ED41B, JpGU2019 U-02)". It is not associated with a conference.

Acknowledgements. We would like to thank WOMEESA network members for their support and engagement. We are grateful to the in-kind support from our respective affiliations who have provided us with time, space and logistical support for networking events and activities. The GSA are thanked for providing data on the gender of GSA members and committees. We are grateful to Sarah Boulton and an anonymous reviewer for their constructive comments that have improved the manuscript and we thank Claudia Alves de Jesus Rydin for editorial handling and support.

Review statement. This paper was edited by Claudia Jesus-Rydin and reviewed by Sarah Boulton and one anonymous referee.

\section{References}

Abbott, A.: Stress, anxiety, harassment: huge survey reveals pressures of scientists' working lives, Nature, 577, 460-461, https://doi.org/10.1038/d41586-020-00101-9, 2020.

Association for Women in the Sciences (AWIS): Women in science: a 2011 snapshot, available at: http://www.awis.org.nz/assets/ Files/AWIS-Stats-2011-Booklet.pdf (last access: 11 February 2020), 2011.

Australian Academy of Science: Women in STEM Decadal Plan, available at: https://www.science.org.au/files/userfiles/ support/reports-and-plans/2019/gender-diversity-stem/ women-in-STEM-decadal-plan-final.pdf (last access: 11 February 2020), 2019.

Australian Bureau of Statistics: 4125.0 - Gender indicators, Australia, Nov 2019, available at: https://www.abs.gov.au/ausstats/ abs@.nsf/mf/4125.0 (last access: 11 February 2020), 2019.

Australian Government: Workplace Gender Equality Act 2012, available at: https://www.legislation.gov.au/Details/ C2016C00895 (last access: 11 February 2020), 2012.

Australian Human Rights Commission: It starts with us: The leadership shadow; chief executive women-male champions of change, available at: https://humanrights.gov.au/our-work/ sex-discrimination/publications/it-starts-us-leadership-shadow (last access: 18 May 2020), 2014.

Australian Human Rights Commission: Change the course: National report on sexual assault and sexual harassment at Australian universities report, available at: https://www. humanrights.gov.au/our-work/sex-discrimination/publications/ change-course-national-report-sexual-assault-and-sexual (last access: 5 February 2020), 2017.

Australian Research Council: Gender equality action plan 2018, available at: https://www.arc.gov.au/policies-strategies/strategy/ arc-gender-equality-action-plan-2018 (last access: 23 February 2020), 2018.

Australian Research Council: Gender and the research workforce. Excellence in research for Australia (ERA) 2018, Australian Research Council, Canberra, Australia, 2019. 
Australian Research Council: Gender outcomes: NCGP trend data, available at: https://www.arc.gov.au/policies-strategies/strategy/ gender-equality-research/gender-outcomes-ncgp-trend-data, last access: 5 February 2020.

Boatright, D., Davies-Vollum, S., and King, C.: Earth science education: The current state of play, Geoscientist, 29, 17-19, 2019.

Bocher, M., Ulvrova, M., Arnould, M., Coltice, N., Mallard, C., Gérault, M., and Adenis, A.: Drawing everyday sexism in academia: observations and analysis of a community-based initiative, Adv. Geosci., 53, 15-31, https://doi.org/10.5194/adgeo53-15-2020, 2020.

Bogle, A: Australian research "has a daversity problem": Analysis shows too many men work mostly with other men, available at: https://www.abc.net.au/news/science/2017-11-24/ australian-research-has-a-daversity-problem/9178786 (last access: 15 February 2020), 2017.

Brooke, J. and Edgington, A.: The wheels on the GeoBus, Nat. Rev. Earth Environ., 1, 89-89, https://doi.org/10.1038/s43017019-0018-1, 2020.

Brower, A. and James, A.: Research performance and age explain less than half of the gender pay gap in New Zealand universities, PLoS One, 15, e0226392, https://doi.org/10.1371/journal.pone.0226392, 2020.

Ceci S. J., Ginther D. K., Kahn S., and Williams W. M.: Women in Academic Science, Psychol. Sci. Public. Interes., 15, 75-141, https://doi.org/10.1177/1529100614541236, 2014.

Clancy, K. B. H., Nelson, R., Rutherford, J. N., and Hinde, K.: Survey of academic field experiences (SAFE): Trainees report harassment and assault, PLoS ONE, 9, e102172, https://doi.org/10.1371/journal.pone.0102172, 2014.

Cohen, D. R.: Australian Geoscience Tertiary Education Profile 2017, available at: https://www.agc.org.au/wp-content/uploads/ 2018/11/AGC-Tertiary-Education-Profile-2017-Report.pdf (last access: 11 February 2020), 2018.

Dutt, K., Pfaff, D. L., Bernstein, A. F., Dillard, J. S., and Block, C. J.: Gender differences in recommendation letters for postdoctoral fellowships in geoscience, Nat. Geosci., 9, 805-808, 2016.

Farland-Smith, D.: How important are same-gender role models to middle school girls? Five characteristics of mentors who sustain middle-school girls' interest in science careers, J. Educ. Train., 2, 1-22, https://doi.org/10.5296/jet.v2i1.5423, 2014.

Fitzsimmons, T. W., Yates, M. S. and Callan, V. J.: Employer of Choice for Gender Equality: Leading practices in strategy, policy and implementation, AIBE Centre for Gender Equality in the Workplace, Brisbane, Australia, 2020.

Geoscience Australia diversity and inclusion strategy, 20192022: https://www.ga.gov.au/_data/assets/pdf_file/0010/89443/ Geoscience-Australia-Diversity-Strategy.pdf (last access: 1 February 2020), 2019.

Giles, S., Jackson, C., and Stephen, N.: Barriers to fieldwork in undergraduate geoscience degrees, Nat. Rev. Earth Environ., 1, 7778, https://doi.org/10.1038/s43017-020-0022-5, 2020.

GNS Science: Annual report 2019, available at: https: //www.gns.cri.nz/content/download/13857/73721/file/

AnnualReport2019.pdf (last access: 1 February 2020), 2019.

Government of South Australia - Office for Women: Guidelines for gender neutral recruitment, available at: https://officeforwomen.sa.gov.au/_data/assets/pdf_file/0016/
48112/DCSI-929-OFW-Gender-Neutral-Bklet_Update_ JUNE17_v2.2.pdf (last access: 28 February 2020), 2017.

Green, K. A., López, M., Wysocki, A., Kepner, K., Farnsworth, D., and Clark, J. L.: Diversity in the workplace: Benefits, challenges, and the required managerial tools, University of Florida, IFAS Extension 1, 1-3, available at: https://edis.ifas.ufl.edu/hr022 (last access: 11 February 2020), 2002.

Greene, S., Ashley, K., Dunne, E., Edgar, K., Giles, S., and Hanson, E.: Toilet stops in the field: An educational primer and recommended best practices for field-based teaching, Birmingham, UK, available at: https://drive.google.com/file/ d/15mLZgZWQvBXQRU_ok7OqnpUmxKObgwAm/view (last access: 8 February 2020), 2019.

Greenway, T.: Why better data is crucial for gender equality, Global Cause, available at: https://www.globalcause.co.uk/women-and-girls/

why-better-data-is-crucial-for-gender-equality/\# (last access: 11 February 2020), 2019.

Greider, C. W., Sheltzer, J. M., Cantalupo, N. C., Copeland, W. B., Dasgupta, N., Hopkins, N., Jansen, J. M., JoshuaTor, L., McDowell, G. S., Metcalf, J. L., McLaughlin, B., Olivarius, A., O'Shea, E. K., Raymond, J. L., Ruebain, D., Steitz, J. A., Stillman, B., Tilghman, S. M., Valian, V., VillaKomaroff, L., and Wong, J. Y.: Increasing gender diversity in the STEM research workforce, Science, 366, 692-695, https://doi.org/10.1126/science.aaz0649, 2019.

Hernandez, P. R., Bloodhart, B., Adams, A. S., Barnes, R. T., Burt, M., Clinton, S. M., Du, W., Godfrey, E., Henderson, H., Pollack, I. B., and Fischer, E. V.: Role modeling is a viable retention strategy for undergraduate women in the geosciences, Geosphere, 14, 2585-2593, https://doi.org/10.1130/GES01659.1, 2018.

International Labour Organisation (ILO): Country profiles - the latest decent work statistics by country, available at: https://ilostat. ilo.org/data/country-profiles/, last access: 24 February 2020.

Jaynes, A. N., MacDonald, E. A., and Keesee, A. M.: Equal representation in scientific honors starts with nominations, Eos, 100, https://doi.org/10.1029/2019EO117855, 2019.

Johnson, J.: Geoscience Australia submission to women in STEM decadal plan, available at: https: //www.ga.gov.au/_data/assets/pdf_file/0004/74776/ GA-Submission-Women-in-STEM-Decadal-Plan.pdf (last access: 11 February 2020), 2018.

Karukstis, K. K.: A horizontal mentoring initiative for senior women scientists at liberal arts colleges, Council on Undergraduate Research Quarterly, vol. 31, issue 2, available at: https://www. cur.org/download.aspx?id=155 (last access: 24 May 2020), 2010.

Kingsley, I.: Evaluating STEM gender equity programs: A guide to effective program evaluation. Office of the Women in STEM Ambassador, Department of Industry, Science, Energy and Resources, Australian Government, available at: https://womeninstem.org.au/research-projects/ national-evaluation-guide/, last access: 24 May 2020.

Larivière, V., Ni, C., Gingras, Y., Cronin, B., and Sugimoto, C. R.: Bibliometrics: Global gender disparities in science, Nature, 504, 211-213, 2013.

Lerback, J. and Hanson, B.: Journals invite too few women to referee, Nature, 541, 455-457, https://doi.org/10.1038/541455a, 2017. 
Lopes, C. A. and Bailur, S.: Gender equality and big data, UN Women, New York, USA, 2018.

McDaugall, M. and Beattie, R. S.: Peer Mentoring at Work, Manag. Learn., 28, 423-437, https://doi.org/10.1177/1350507697284003, 1997.

Mencarini, L.: Gender Equity, in: Encyclopedia of quality of life and well-being research, edited by: Michalos, A. C., Springer, Dordrecht, the Netherlands, 2014.

Miller, D. I., Nolla, K. M., Eagly, A. H., and Uttal, D. H.: The development of Children's gender-science stereotypes: A metaanalysis of 5 decades of U.S. Draw-A-Scientist studies, Child Dev., 89, 1943-1955, https://doi.org/10.1111/cdev.13039, 2018.

Mills, J., Bastalich, W., Franzway, S., Gill, J., and Sharp, R.: Engineering in Australia: An uncomfortable experience for women, Journal of Women and Minorities in Science and Engineering, 12, 135-154, 2006.

Ministry of Education: Retention and achievement, available at: https://www.educationcounts.govt.nz/statistics/ tertiary-education/retention_and_achievement (last access: 11 February 2020), 2018a.

Ministry of Education: Participation in tertiary education in New Zealand, available at: https://www.educationcounts.govt.nz/ statistics/tertiary-education/participation (last access: 11 February 2020), 2018b.

Mukasa, S.: Underrepresentation of women and minority awardees in geoscience societies, Elements, 77-78, available at: https://www.geochemsoc.org/files/8314/1233/7360/ MukasaElementsDiversityApril2009.pdf (last access: 24 May 2020), 2009.

Nathan, S.: Women in New Zealand geoscience, GSNZ Journal of the Historical Studies Group, 65, 22-42, 2020.

Naylor, R. and Mifsud, N.: Structural inequality in higher education: Creating institutional cultures that enable all students, La Trobe University, available at: https://www.ncsehe.edu.au/ wp-content/uploads/2019/09/NaylorMifsud-FINAL.pdf (last access: 22 February 2020), 2019.

NIWA Taihoro Nukurangi: Annual Report 2016/17, available at: https://niwa.co.nz/sites/niwa.co.nz/files/NIWA_Annual_ Report_2017_PART-1_pp1-51.pdf (last access: 11 February 2020), 2017.

NIWA Taihoro Nukurangi: Annual Report 2018/19, available at: https://niwa.co.nz/sites/niwa.co.nz/files/ FINALNIWAAnnualReport2018-19.pdf (last access: 11 February 2020), 2019a.

NIWA Taihoro Nukurangi: Science Guiding our Future, Statement of Corporate Intent 2019/20, available at: https://niwa.co. nz/sites/niwa.co.nz/files/NIWA_SCI_2019-20_web.pdf (last access: 11 February 2020), 2019b.

Núñez, A-M, Rivera, J., and Hallmark, T.: Applying an intersectionality lens to expand equity in the geosciences, Journal of Geoscience Education, 68, 97-114, https://doi.org/10.1080/10899995.2019.1675131, 2020.

Organisation for Economic Co-operation and Development (OECD): Gender wage gap (indicator), available at: https://data. oecd.org/earnwage/gender-wage-gap.htm, last access: 11 February 2020.

Ovseiko, P. V., Pololi, L. H., Edmunds, L. D., Civian, J. T, Daly, M., and Buchan, A. M.: Creating a more supportive and inclusive university culture: a mixed-methods interdisci- plinary comparative analysis of medical and social sciences at the University of Oxford, Interdiscipl. Sci. Rev., 44, 166-191, https://doi.org/10.1080/03080188.2019.1603880, 2019.

Ritchie, H. and Roser, M,: Gender ratio, our world in data, available at: https://ourworldindata.org/gender-ratio (last access: 11 February 2020), 2019.

Royal Society of Chemistry: Rethinking recognition: Science prizes for the modern world, available at: https://www.rsc.org/globalassets/ 22-new-perspectives/talent/re-thinking-recognition/

review-of-recognition-report---final-singles.pdf (last access: 11 February 2020), 2019.

Royal Society Te Apārangi: Information on the 2018 Marsden Fund round, available at: https://www.royalsociety. org.nz/what-we-do/funds-and-opportunities/marsden/ marsden-announcements/info-2018-marsden-fund-round/ (last access: 24 February 2020), 2019.

Rust, B.: Hidden Networks: Māori and Pacific Island women in science, Te Punaha Matatini, available at: https://www.tepunahamatatini.ac.nz/2018/02/12/a-story-ofsome-maori-and-pacific-island-women-in-science-from-the14th-century-to-today/ (last access: 11 February 2020), 2015.

Schwab, K., Samans, R., Zahidi, S., Leopold, T. A., Ratcheva, V., Hausmann, R., and Tyson, L. D.: The global gender gap report 2017, available at: http://www3.weforum.org/docs/WEF_ GGGR_2017.pdf (last access: 14 February 2020), 2017.

Science in Australia, Gender Equity (SAGE): Gender equity in STEMM, available at: https://www.sciencegenderequity.org.au/ gender-equity-in-stem/ (last access: 23 February 2020), 2016.

Statistics New Zealand: Women at work: 1991-2013, available at: http://archive.stats.govt.nz/browse_for_stats/people_and_ communities/Women/women-occupation.aspx (last access: 11 February 2020), 2015.

$\mathrm{Su}$, R. and Rounds, J.: All STEM fields are not created equal: People and things interests explain gender disparities across STEM fields, Front. Psychol., 6, 189, https://doi.org/10.3389/fpsyg.2015.00189, 2015.

Vila-Concejo, A., Gallop, S. L., Hamylton, S. M., Esteves, L. S., Bryan, K. R., Delgado-Fernandez, I., Guisado-Pintado, E., Joshi, S., da Silva, G. M., Ruiz de Alegria-Arzaburu, A., Power, H. E., Senechal, N., and Splinter, K.: Steps to improve gender diversity in coastal geoscience and engineering, Palgrave Commun., 4, 103, https://doi.org/10.1057/s41599-018-0154-0, 2018.

Waltho, A.: Inclusion and diversity in Australian geoscience, AIG News, 127, 36-38, 2017.

Waltho, A.: Australian geoscience today, available at: https: //www.aig.org.au/blog/2019/01/02/australian-geoscience-today/ (last access: 12 February 2020), 2019.

Winchester, H. P. M. and Browning, L.: Gender equality in academia: a critical reflection, J. High. Educ. Policy Manag., 37, 269-281, https://doi.org/10.1080/1360080X.2015.1034427, 2015.

Workplace Gender Equality Agency: Australia's gender pay gap statistics, available at: https://www.wgea.gov.au/data/fact-sheets/ australias-gender-pay-gap-statistics (last access: 11 February 2020), 2019.

World Bank: Women, business and the law 2020, available at: https: //wbl.worldbank.org/, last access: 11 February 2020. 
World Economic Forum: Gender equality? It starts with data, available at: https://www.weforum.org/agenda/2017/09/ gender-equality-it-starts-with-data (last access: 11 February 2020), 2019a.

World Economic Forum: Global gender gap report 2020, available at: http://www3.weforum.org/docs/WEF_GGGR_2020.pdf (last access: 11 February 2020), 2019 b.
Yang, Y., Chawla, N. V., and Uzzi, B.: A network's gender composition and communication pattern predict women's leadership success, P. Natl. Acad. Sci. USA, 116, 2033-2038, https://doi.org/10.1073/pnas.1721438116, 2019. 